\title{
LIBERDADE (<=S=>) EM DISCRICIONARIEDADE?! RESTRIÇÕES AO DIREITO DE LIBERDADE NO CONTEXTO PANDÊMICO
}

\author{
FREEDOM (<=S=>) IN DISCRETIONARETY?! RESTRICTIONS ON THE RIGHT TO \\ FREEDOM IN THE CONTEXT OF THE PANDEMIC
}

\section{¿¿LIBERTAD (<=S=>) EN DISCRECIONALIDAD?! RESTRICCIONES AL DERECHO DE LIBERTAD EN EL CONTEXTO PANDÉMICO}

\section{Airto Chaves Junior ${ }^{1}$}

\section{Thiago Aguiar de Pádua²}

Licença CC BY:

Artigo distribuído sob os termos Creative Commons, permite uso e distribuição irrestrita em qualquer meio desde que $o$ autor credite a fonte original.

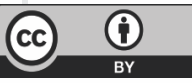

\begin{abstract}
Resumo: A pesquisa objetiva verificar se medidas de restrição à liberdade ambulatorial consubstanciadas no lockdown e no fechamento de vias terrestres por parte de governos locais para prevenção do novo coronavírus tem base constitucional. Para tanto, investiga-se a "nova questão constitucional" inserida na Teoria dos Direitos Fundamentais, para que sejam examinados os limites à discricionariedade daqueles que atuam em nome do Estado. Esses limites são analisados a partir do estudo dos cinco passos do teste de proporcionalidade: I. Objetivo legítimo; II. Meio legítimo; III. Adequação; IV. Necessidade; e V) Sopesamento [ou ponderação]. Ao final do estudo, conclui-se que, apesar de aprovada nos passos I e III, essas restrições ao direito à liberdade são reprovadas nas fases II, IV e V, pois desproporcionais. O método de pesquisa será o indutivo, sempre subsidiado pela pesquisa bibliográfica e qualitativa direcionada à consulta pormenorizada de teóricos do Direito Constitucional, bem como da legislação brasileira.
\end{abstract}

Palavras-chave: Liberdade; Discricionariedade; Pandemia; Restrições. Proporcionalidade.

Abstract: The aim of this research is to examine the constitutional basis of the government measures to restrict the freedom to come and go, embodied in the blocking and closure of land routes by local governments in an attempt to halt the spread of the new coronavirus. It investigates the "new constitutional issue", inserted in the Theory of Fundamental Rights, in order to examine the limits of discretionarity of those acting on behalf of the State. These limits are analyzed through the study of the five steps of the proportionality test: I. Legitimate objective; II. Legitimate means; III. Adequacy; IV. Need; and V) balance [or weighting]. At the end of the study, we conclude that despite passing steps I and III, these restrictions of the right to freedom fail in steps II, IV and V, as they are disproportionate. The research method used is inductive, supported by bibliographic and qualitative research, through a detailed search on theorists of Constitutional Law, as well as Brazilian legislation.

\footnotetext{
1 Doutor e Mestre em Ciência Jurídica pelo Programa de Pós-Graduação Stricto Sensu em Ciência Jurídica da UNIVALI. Doutor em Direito pela Universidade de Alicante, Espanha; Professor do Programa de Pós-Graduação Stricto Sensu em Ciência Jurídica (Cursos de Mestrado e Doutorado) da Universidade do Vale do Itajaí. Professor do Curso de Direito da mesma instituição. Professor da Escola do Ministério Público do Estado de Santa Catarina. Professor da Escola da Magistratura do Estado de Santa Catarina. Advogado. E-mail: oduno@hotmail.com.

2 Doutor e Mestre em Direito pelo Programa de Pós-Graduação Stricto Sensu em Direito do UniCEUB. Professor do Programa de PósGraduação Stricto Sensu em Direito do UDF - Centro Universitário do Distrito Federal. Membro do Centro de Estudos Constitucionais - CBEC. Vice-Presidente da Comissão de Estudos Constitucionais da ANACRIM - Associação Nacional da Advocacia Criminal. Advogado. E-mail: professorthiagopadua@gmail.com.
} 
Keywords: Freedom; Discretion; Pandemic; Restrictions; Proportionality.

Resumen: La investigación objetiva verificar si medidas de restricción a la libertad ambulatorial consubstanciadas en el Lockdown y el cierre de vias terrestres por parte de gobiernos locales para prevención del nuevo coronavírus tiene base constitucional. Para tanto, se investiga la "nueva cuestión constitucional" inserta en la Teoría de los Derechos Fundamentales, para que sean examinados los límites a la discrecionalidad de aquellos que actúan en nombre del Estado. Esos límites son analizados a partir del estudio de los cinco pasos del test de proporcionalidad: I. Objetivo legítimo; II. Medio legítimo; III. Adecuación; IV. Necesidad; y V) Ponderación. Al final del estudio, se concluye que, a pesar de aprobado en los pasos I y III, estas restricciones al derecho a la libertad son reprobadas en las fases II, IV y V, pues desproporcionales. El método de investigación será el inductivo, siempre subsidiado por la investigación bibliográfica y cualitativa direccionada a la consulta pormenorizada de teóricos del Derecho Constitucional, bien como de la legislación brasileña.

Palabras clave: Libertad; Discrecionalidad; Pandemia; Restricciones. Proporcionalidad.

\section{INTRODUÇÃO}

Este trabalho está inserido na linha de pesquisa Principiologia Constitucional e Política do Direito e procurará refletir sobre um tema fundamental, antigo e complexo: a liberdade de ir, vir e ficar. E essa reflexão será realizada na imersão do contexto pandêmico gerado pela Covid-19, sobretudo na discricionariedade operada por gestores públicos - Governadores de Estados e Prefeitos de Municípios - no cerceamento da liberdade ambulatorial.

Inicialmente, abordar-se-á a perspectiva de uma "nova questão constitucional" dentro do seio da Teoria do Direito Constitucional, do Estado de Direito e dos limites à discricionariedade daqueles que atuam em nome do Estado. Essas reflexões serão importantes para que sejam tratadas, na sequência, a relação entre o Estado de Liberdade e o Direito, afim de que sejam resgatadas as linhas centrais e os fundamentos da liberdade sob o viés jusfilosófico.

A erupção do paradigma do constitucionalismo, demais de sua central relação com a manutenção do Estado de Direito, proteção contra atos de poder governamental e fazer respeitar os direitos fundamentais, é elemento de central importância no diálogo realizado e figurará no próximo campo de abordagem.

Perpassa, além de outras perspectivas, a relevância da compreensão da rigidez constitucional como conceito cunhado há muitos anos e cuja razão de ser parece passar despercebida nos dias que correm. Esses desenvolvimentos contemporâneos datados do ponto de mutação radicado a partir dos horrores da Segunda Grande Guerra surgiram, exatamente, para fazer jamais esquecer os abusos perpetrados por um poder de controle que, rapidamente, pode ser convolado em arbítrio. 
Todo esse alinhamento teórico será objeto de análise para que, a partir do princípio da proporcionalidade como vetor (princípio dos princípios) de checagem da validade da intervenção e restrição de direitos fundamentais, seja possível responder à seguinte pergunta: é adequada a restrição à liberdade sem base na Constituição Federal?

Conforme se verá, muitas das vezes a proporcionalidade é manipulada para que se relativizem direitos fundamentais sob o argumento de que "não existem direitos absolutos". No entanto, no que se refere à liberdade ambulatorial, os argumentos que procuram justificar restrições determinadas por prefeitos e governadores em portarias e/ou decretos exarados no contexto pandêmico não parecem encontrar abrigo constitucional, vez que reprovados no teste da proporcionalidade.

O momento em que vive o Brasil e o mundo é altamente complexo e polarizado politicamente. Há decisões judiciais de todos os níveis e, em diversas esferas de poder em que se buscou equacionar a competência concorrente entre gestores nos níveis federal, estadual e municipal, abusos passaram a ser objeto de novas deliberações. E é exatamente nos recorrentes abusos que se perceberam as restrições à liberdade de ir, vir e ficar, como direito fundamental. Dissociada de seus fundamentos, suas raízes e do leitmotiv de sua proteção na Constituição Federal de 1988, torna-se mais importante do que nunca uma revisitação para que se evite a naturalização da lesão às suas bases.

Permitir abusos de gestores, não importando a que nível pertençam, e, neste sentido, o mesmo valendo para filiação partidária ou inclinação ideológica, significa admitir não apenas o uso da discricionariedade, pesadelo e problema tanto para jusnaturalistas quanto para juspositivistas, problema, inclusive, jamais solucionado por pós-positivistas. Significa, além disso, manipulação teorética em perspectiva constitucional, desconectada do texto da Constituição de 1988 e que parte de premissas equivocadas, o que representa um problema teórico com sérias consequências constitucionais, pois estilhaça o tecido da rede de proteção urdida exatamente para evitar os abusos que muitos parecem dispostos a tolerar de maneira ad hoc nos dias de hoje.

Será a partir do desenvolvimento de tais discussões teóricas que a pesquisa transitará. O método de pesquisa será o indutivo, sempre subsidiado pela pesquisa bibliográfica e qualitativa direcionada à consulta pormenorizada de teóricos do Direito Constitucional, bem como da legislação brasileira. 


\section{ENTRE TEORIA CONSTITUCIONAL, ESTADO DE DIREITO E LIMITES AO PODER: DISCRICIONARIEDADE}

Gunther Teubner ${ }^{3}$ chama atenção para uma "nova questão constitucional", diferente das questões constitucionais dos séculos XVIII e XIX, as quais se relacionavam, especialmente, com a "liberação das energias do poder político do Estado Nacional, e, simultaneamente, da limitação das mesmas em um Estado de Direito". Na chamada "nova questão constitucional", de maneira distinta, cuida-se de "liberar energias sociais completamente diferentes, especialmente perceptíveis na economia", e também na ciência e na tecnologia, inclusive na medicina e nos meios de comunicação em massa, além de restringir efetivamente seus efeitos destrutivos.

Isso conduz a um necessário refinamento das reflexões contemporâneas, mormente em tempos como os hoje vivenciados (de Pandemia de Covid-19), em que os diversos Estados Nacionais precisam lidar com sérias ameaças ao direito à saúde e com o direito de conviver em meios urbanos e ambientais saudáveis, além das severas limitações a inúmeros direitos fundamentais. Neste sentido, Richard Fallon, refletindo sobre meios e critérios de adoção da "melhor teoria constitucional"4, observa a existência de inúmeros desenvolvimentos teóricos concorrentes entre si, de fato verificáveis, a partir do questionamento sobre como os juízes e os tribunais devem interpretar e aplicar a Constituição, muito embora exista um certo grau de concordância (implícita) acerca dos critérios que precisam ser satisfeitos, especialmente sobre a necessidade de fazer valer o Estado de Direito, preservar a democracia política e fazer respeitar direitos fundamentais 5 .

3 Teubner menciona, ainda, algo digno de registro: "Nos últimos anos, uma série de escândalos públicos chamou atenção para ä nova questão constitucional. Violações de direitos humanos por empresas multinacionais; decisões controversas da Organização Mundial do Comércio que, em nome do livre comércio global, ameaçam a proteção ao meio ambiente e à saúde; doping esportivo; corrupção na medicina e na ciência; ameaças à liberdade de expressão por intermediários privados na internet; interferências massivas na esfera privada decorrentes da coleta e retenção de dados por organizações privadas; e, com força especial, a liberação de riscos catastróficos nos mercados financeiros mundiais todos esses fenômenos levantam não apenas problemas políticos e jurídicos de regulação, mas também problemas constitucionais em sentido estrito. No plano de fundo desses escândalos, situa-se o elemento constitutivo fundamental das dinâmicas sociais, e não uma mera questão de implementação de "policies" de regulação estatal (...) Os escândalos mencionados extrapolam as fronteiras do Estado Nacional em duplo sentido. Constitucionalismo além do Estado Nacional quer dizer duas coisas: os problemas constitucionais se situam fora das fronteiras do Estado Nacional, em processos políticos transnacionais; e, simultaneamente, fora do setor político institucionalizado, nos setores 'privados' da sociedade mundial". Cfr. TEUBNER, Gunther. Fragmentos constitucionais: constitucionalismo social na globalização. São Paulo: Saraiva, 2016, p. 15.

4 O tema, evidentemente, também remonta ao debate Posner /Dworkin /Sunstein sobre o uso de teoria no âmbito do direito. Cfr. POSNER, Richard. Conceptions of legal "Theory": a Response to Ronald Dworkin. Arizona State Law Journal, vol. 29, 1997; SUNSTEIN, Cass. From Theory to Practice Order of the Coif Lecture: Response. Arizona State Law Journal, vol. 29, 1997; DWORKIN, Ronald. In Praise of Theory. Arizona State Law Journal, vol. 29, 1997, p. 353-376; DWORKIN, Ronald. Reply. Arizona State Law Journal, vol. 29, 1997, p. 431-456; DWORKIN, Ronald. Darwin's New Bulldog. Harvard Law Review, vol. 111, 1997-1998, p. 1718-1738.

5 Em tradução livre: "As pessoas preocupadas com o direito constitucional enfrentam um grande número teorias constitucionais concorrentes, que oferecem relatos conflitantes de como os juízes devem interpretar e aplicar a Constituição. Avaliação de tais teorias precisam se basear parcialmente em bases normativas. Além disso, existe um grau surpreendente de concordância implícita entre os teóricos sobre os critérios que uma teoria constitucional deve satisfazer. Além de 'encaixar' tanto o texto da Constituição escrita quanto a prática constitucional, as teorias constitucionais devem ser julgadas com base em sua capacidade de (i) manter o estado de direito, (ii) preservar oportunidades justas para a democracia política e (iii) proteger um conjunto moral e politicamente aceitável de direitos substantivos. Determinando qual teoria constitucional promover melhor esses objetivos requer um cálculo parcialmente instrumental, incluindo uma avaliação de quem provavelmente nossos juízes e juízes serão. No entanto, a necessidade de selecionar uma teoria por motivos instrumentais não justificar manipulação caso a caso sem princípios. Uma boa teoria constitucional deve impor restrições àqueles que a aceitam". Cfr. FALLON JR., Richard. How to choose a Constitutional Theory. California Law Review, v. 87, 1999. 
Crucial acaba sendo a não manipulação das teorias, bem como, essencialmente, a imposição de limitação àqueles que a aceitam. Conforme Claus Wilhem Canaris ${ }^{6}$, as teorias jurídicas também devem obedecer aos requisitos impostos pela filosofia da ciência, quais sejam, consistência e verificabilidade. Neste sentido, uma teoria será sempre inconsistente se tiver uma contradição lógica, pois é comum no seio do direito as chamadas "contradições valorativas". Portanto, uma abordagem que seja consistente e verificável sobre problemas jurídicos, necessariamente, precisa estar de acordo com o Estado de Direito, proteção às condições da democracia política e respeito aos direitos fundamentais, e jamais estar atrelada a gostos pessoais ou manipulações de ocasião (ad hoc).

Dito isto, como elemento prévio das próximas reflexões, também se precisa mencionar que, no âmbito jurídico, dois modelos tentaram formatar o conceito de Direito, quais sejam, o Direito Natural e o Positivismo Jurídico (ambos com inúmeras variantes expositivas), centrais para a compreensão do tema abordado. Em linhas gerais, o Direito Natural possui três pontos que se complementam: a) a perspectiva de que o direito positivo deve ser sempre visto desde sua necessária concordância com conteúdo metafísicos e superiores (ou seja, pressupostos e naturais); b) a pressuposição de que tais conteúdos decorreriam de fonte superior, universal e imutável (podendo ser a natureza, um deus, algum ideal de justiça, etc.); e, c) a assunção de que tais conteúdos deveriam prevalecer sempre em contraposição com o direito positivo que com ele esteja em dissonância?

A seu turno, em contraponto, o positivismo jurídico possuiria em Hans Kelsen um opositor ferrenho (embora não seja o único, e nem o primeiro positivista jurídico ${ }^{8}$ ), que buscou submeter o Direito Natural perante o "Tribunal da Ciência", com ao menos seis pontos de contraste e questionamento: (i) Monismo ontológico9; (ii) Padrão epistemológico relativístico'io; (iii) Otimismo

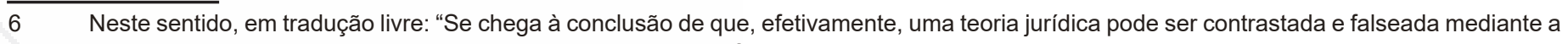
comparação com os enunciados básicos. Estes possuem seu fundamento em normas que podem ser obtidas da Lei, ou com os instrumentos próprios do desenvolvimento do Direito que supera a Lei. Quando tal enunciado básico está em contradição com o enunciado básico correspondente, que resulta da realização consequente de uma teoria, ela restará falseada. "Salvá-la", mediante uma pura hipótese ad hoc é inaceitável; tal ocorre quando a hipótese se exaure com a supressão da dificuldade em questão, vale dizer, quando não apresenta um conteúdo informativo que a transcenda. Da eficácia de uma teoria deve se diferenciar a possibilidade de sua falsificação, pois inclusive as teorias de alta eficácia podem ser falseadas". Cfr. CANARIS, Claus Wilhem. Función, estrutura y falsación de las teorias jurídicas. Trad. Daniela Brückner y Luis de Castro. Madrid: Civitas, 1995, p. 71-98.

7 BEDIN, Gilmar Antônio. Direito Natural. Em: BARRETO, Vicente Paulo [Coord.]. Dicionário de Filosofia do Direito. São Leopoldo: Unisinos, 2009, p. 240-241; COELHO, Luiz Fernando. Aulas de introdução ao direito. Barueri-SP: Manole, 2004, p. 124.

8 Para uma abordagem relativamente profunda, em língua nacional, conferir o texto de Lenio Streck et al.; para uma exaustiva abordagem de caráter analítico, confira-se Pierluigi Chiassoni. STRECK, Lenio Luiz; ORTIZ MATOS, Daniel. Mitos sobre o positivismo jurídico: uma leitura para além do senso comum teórico. Revista UNIFESO - Humanas e Sociais Vol. 1, n. 1, 2014; STRECK, Lenio Luiz; RAATZ, I.; MORBACH, Gilberto. Desmistificando o positivismo de Jeremy Bentham: sua codificação utilitarista e a rejeição ao stare decisis como autorização para errar por último. Revista Brasileira de Direito Processual, v. 99, p. 221-242, 2017; STRECK, Lenio Luiz. Kelsen e o positivismo jurídico contemporâneo: notas de um (possível) acerto de contas. Revista del Posgrado en Derecho de la UNAM, v. 9, p. 145-169, 2018; CHIASSONI, Pierluigi. El discreto placer del positivismo juridico. Bogotá: Externado, 2016.

9 Conforme abordado: "existe apenas uma realidade passível de investigação científica, qual seja, a realidade da experiência, o mundo dos fenômenos naturais e sociais que podem ser percebidos por nossos sentidos e ordenados pela razão (nossa 'faculdade de conhecer')". Cfr. CHIASSONI, Pierluigi. Kelsen on Natural Law Theory An Enduring Critical Affair, Revus: Journal for Constitutional Theory and Philosophy of Law, 23, 2014.

10 Neste sentido: "não existe 'verdade' absoluta, mas apenas verdades baseadas na experiência relacionadas a critérios racionais de investigação científica". Cfr. CHIASSONI, Pierluigi. Kelsen on Natural Law Theory An Enduring Critical Affair, Revus: Journal for Constitutional Theory and Philosophy of Law, 23, 2014. 
moderado epistemológico em relação à razão e aos sentidos ${ }^{11}$; (iv) Pessimismo epistemológico em relação a diferentes ferramentas de investigação pretendidas ${ }^{12}$; (v) Validade epistêmica universal ${ }^{13}$; e, (vi) Subjetivismo metaético e não cognitivismo ${ }^{14}$.

Segundo Kelsen, um dos grandes problemas do Direito Natural é a "discricionariedade", pois envolve a questão da reivindicação ontológica inerente ao consequente processo de individualização da norma geral para a norma individual: "o processo de individualização de normas gerais materiais, na medida em que ordens legais positivas são consideradas, é necessariamente um processo discricionário"15, ou seja, um processo de substituição discricionária de normas gerais por normas individuais (não necessariamente "correspondentes"), que dependeria não apenas de atos de conhecimento, mas também de atos de vontade (o órgão de aplicação da lei deve estabelecer "constitutivamente" um caso individual do mesmo tipo considerado no antecedente de uma norma geral, bem como, também, deve estabelecer "constitutivamente" quais consequências jurídicas se seguem a ele).

Contudo, a discricionariedade também é um problema inerente ao positivismo jurídico (inclusive em suas diversas tipologias). Sobre este modelo, ganha relevo a adequação formal da norma, e não do conteúdo ético, sociológico ou ideológico. Aqui há uma verdadeira cisão teórica entre validade e quaisquer considerações acerca da legitimidade dos textos normativos, conforme recorda Mário Losano, a partir de Karl Bergbohm, pois existem dois princípios elementares comuns a todas as vertentes positivistas $^{16}$ : (a) a consideração de que apenas (e exclusivamente) o direito positivo seria Direito, que deveria ser produzido por autoridade devidamente constituída, bem como por meio de procedimentos previamente especificados; (b) de que o direito posto pela autoridade competente, devidamente constituída (e que tenha obedecido os procedimentos formais pertinentes) seria a norma juridicamente válida, e, neste sentido, deveria ser obedecida acima de qualquer questionamento.

11 Afirma-se: "mesmo que sejam incapazes de levar nossas investigações além dos limites da experiência, mesmo que seu uso exija suposições básicas e o constante exercício de dúvida epistêmica, a razão e os sentidos devem ser considerados como ferramentas bastante eficientes e confiáveis para investigações empíricas". Cfr. CHIASSONI, Pierluigi. Kelsen on Natural Law Theory An Enduring Critical Affair, Revus: Journal for Constitutional Theory and Philosophy of Law, 23, 2014.

12 Em termos gerais: "por mais imperfeitos que sejam, a razão e os sentidos são as únicas ferramentas de investigação científica disponíveis para nós; outras pretensas ferramentas realmente não fazem nada pela 'busca da verdade [científica]', sendo equivalentes a formas mais ou menos abertas de "imaginação que cumprem desejos". Cfr. CHIASSONI, Pierluigi. Kelsen on Natural Law Theory An Enduring Critical Affair, Revus: Journal for Constitutional Theory and Philosophy of Law, 23, 2014.

13 Aponta-se: "a abordagem crítico-científico se mantém não apenas para a investigações sobre o reino de fatos (conectados de maneira causal), mas também para aqueles sobre o domínio de normas e valores. O competente Tribunal para decidir sobre a Teoria do Direito Natural (e, de maneira mais geral, sobre direito, política, moralidade e teorias) é o mesmo que, digamos, ouviria um caso sobre uma suposta descoberta terapêutica milagrosa na ciência médica”. Cfr. CHIASSONI, Pierluigi. Kelsen on Natural Law Theory An Enduring Critical Affair, Revus: Journal for Constitutional Theory and Philosophy of Law, 23, 2014.

14 Sobre o tema: "do ponto de vista da ciência, o subjetivismo (não há normas morais objetivas, nem valores morais objetivos; normas e valores morais dependem de atos humanos de vontade que espelhem suas preferências, emoções, interesses) e o não-cognitivismo (a razão, nossa faculdade de conhecimento, não pode resolver o problema da justiça por si só, nem qualquer outro problema prático) são as únicas visões meta-éticas aceitáveis. História, sociologia, psicologia e antropologia convergem para apoiar esta conclusão". Cfr. CHIASSONI, Pierluigi. Kelsen on Natural Law Theory An Enduring Critical Affair, Revus: Journal for Constitutional Theory and Philosophy of Law, $23,2014$.

15 KELSEN, Hans. The Idea of Natural Law. In: Essays in Legal and Moral Philosophy [1928]. Selected and Introduced by Ota Weinberger. Dordrecht \& Boston (Mass.): Reidel, 1973, p. 39-56.

16 LOSANO, Mário G. Sistema e estrutura no direito: o século XX. v. II. Trad. de Luca Lamberti. São Paulo: Editora WMF Martins Fontes, 2010, p. 33, nota de rodapé n. 50 . 
Neste caso, a reforma legislativa seria permitida apenas por meio da autoridade competente, ou em outros termos, aquilo que Bobbio ${ }^{17}$ viria chamar de "teoria da obediência" (Gesetz ist Gesetz - lei é lei).

Prosseguindo para além dos "conceitos fundamentais da doutrina positivista", observam-se as principais teses desse modelo, considerando o fato de que, nas palavras de Eugenio Bulygin ${ }^{18}$, por se tratar de modelo que trouxe adesão de variados e distintos pensadores, despiciendo dizer que nem todos trilham o mesmo aspecto e nem subscrevem as teses centrais do positivismo, sejam elas: (i) a diferenciação entre dever-ser e ser, originalmente radicada em Bentham; (ii) postura negacionista de uma conexão entre moral e Direito (Bentham, Kelsen, dentre outros); (iii) a perspectiva de que dos fatos sociais depende a existência e o conteúdo do direito - o chamado postulado das fontes sociais, de Joseph Raz; (iv) o denominado ceticismo ético (de Hans Kelsen e Alf Ross); (v) o negacionismo do direito natural, uma vez que só o direito positivo seria direito (Hans Kelsen e Alf Ross); (vi) a proposição da teoria jurídica como ciência (Kelsen); (vii) a perspectiva da filosofia como uma abordagem conceitual (H. Hart); e, por último, (viii) a perspectiva de que tribunais e juízes disporiam de discricionariedade para a solução de casos dúbios (H. Hart). Dworkin também admite a discricionariedade ${ }^{19}$, e ela também está presente na ideia de Kelsen ${ }^{20}$ sobre a moldura da norma, na diferenciação entre interpretação autêntica e interpretação inautêntica, que remata ato de vontade $(\text { de poder })^{21}$.

Por isso, evidentemente, Kelsen também é chamado de realista jurídico (realismo jurídico do tipo Vienense). Olivier Jouanjan assevera que a ciência do direito, para Kelsen, estaria posta num sentido puro (purificada), muito embora o mesmo não valha para a prática. ${ }^{22}$ Na regulação da interpretação autêntica, levado a um segundo plano, como se fosse uma simples e mera "política do Direito", ${ }^{23}$ Kelsen (em seu normativismo) abre as portas para um decisionismo escancarado e se transforma "em um realismo jurídico radical"24.

17 BOBBIO, Norberto. O positivismo jurídico: lições de filosofia do direito. trad. e notas Márcio Publiesi, Edson Bini, Carlos Rodrigues. São Paulo: Ícone, 2006, p. 133.

18 BULYGIN, Eugenio. II positivismo giuridico. A cura di Pierluigi Chiassoni, Ricardo Guastini e Giovani Ratti. Milano: Dott. A. Giuffrè Editore, 2007, p. 3-5.

19 DWORKIN, Ronald. ¿Es el derecho um sistema de normas? Em: La filosofia del derecho. Ronald Dworkin (comp.), Miguel Carbonell (pról.), Javier Sáinz de los Terreros (trad.), 2. ed. México: FCE, 2014, p. 107-109.

20 Acerca do tema "moldura da norma", observe-se a referência de Lenio Streck, na perspectiva da análise kelseniana: "É importante registrar que a palavra em alemão Bild pode ser traduzida de vários modos. Tradicionalmente, na obra Teoria pura do direito, tem sido vertida como "moldura". Mas também significa imagem ou ideia. Lendo o texto original de Kelsen, veremos que "ideia" ou "imagem" podem se tornar coerentes com o contexto. Não esqueçamos o paradigma filosófico no qual está inserido Hans Kelsen e como ele via a relação cognitiva. Ora, Kelsen não era um positivista exegético. Sua obra vem para superar essa concepção de positivismo. O seu positivismo é normativista. Ele não separa o direito da moral, mas, sim, a ciência do direito da moral. Para Kelsen, o cientista faz um ato de conhecimento, descritivo, não prescritivo; já o aplicador da lei faz um ato de vontade (acrescento poder). Juiz não faz ciência e, sim, política jurídica. Sua preocupação com relação à ciência do direito é de que o intérprete tem uma ideia (ou imagem) da lei (do seu texto)." Em: STRECK, Lenio Luiz. Verdade e Consenso: constituição, hermenêutica e teorias discursivas. 5. ed. São Paulo: Saraiva, 2014, p. 35, nota 7.

21 KELSEN, Hans. Teoria pura do direito. Trad. João Baptista Machado, 8. ed., São Paulo: WMF Martins Fontes, 2009, p. 388.

22 JOUANJAN, Olivier. De Hans Kelsen a Friedrich Müller - método jurídico sob o paradigma pós-positivista. Em: MÜLLER, Friedrich. 0 novo paradigma do direito: introdução à teoria e metódica estruturantes. 3. ed., rev. atual. e ampl. São Paulo: Revista dos Tribunais, 2013 , p. 215.

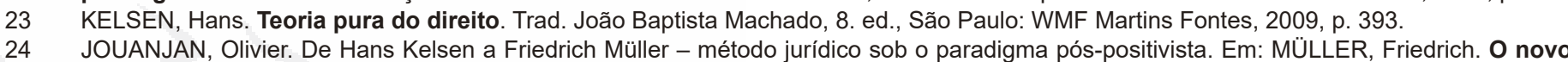
paradigma do direito: introdução à teoria e metódica estruturantes. 3. ed., rev. atual. e ampl. São Paulo: Revista dos Tribunais, 2013, p. 216. 
Também essa é a arguta percepção de Pierluigi Chiassoni, que destaca que as questões relacionadas à correta interpretação de textos jurídicos, ou a correta solução de conflitos do ponto de vista normativo, são postas por Kelsen como mera política jurídica, ou legal politics. ${ }^{25}$ Por este motivo, e ressaltando um grupo das características centrais do realismo jurídico (realistic jurisprudence) - no bojo das quais, evidentemente, se encontra a discricionariedade judicial ${ }^{26}$-, o jurista genovês também conclui que Hans Kelsen seria um realista, criando a expressão Wiener Realism. ${ }^{27}$ Ou seja, buscando superar o problema da discricionariedade do Direito Natural, o Positivismo Jurídico também caiu nas malhas do mesmo problema que buscou suplantar.

Desse modo, verifica-se que a luta do direito e das diversas matrizes formativas dos sistemas jurídicos contemporâneos é uma luta pela redução e pelo estrangulamento da arbitrariedade (discricionariedade) com a busca constante pela limitação do poder, essenciais para a ideia mesma de Estado de Direito Constitucional. Contenção do poder dos governantes, na impugnação ao seu agir discricionário, e na mesma intensidade em que também foi essa a ideia que presidiu, e ainda hoje preside, os diversos modelos de pretensão de formatação dos sistemas jurídicos. Em uma breve síntese, cuida-se da eterna busca pelo equilíbrio da liberdade.

No âmbito constitucional, a atual discussão jurídica sobre as medidas de proteção e combate contra o novo coronavírus (Covid-19) trazem à lume um debate que, se por um lado camufla (ou não aborda apropriadamente) a temática do problema do arbítrio e da discricionariedade no âmbito jurídico, por outro lado, faz recordar o intenso debate sobre as medidas de restrição após o atentado às Torres Gêmeas no 11 de setembro em solo americano (o Ato Patriota), bem como, dali, o instigante debate travado entre Bruce Ackerman ${ }^{28}$ (de um lado) e Laurence Tribe ${ }^{29}$ e Patrick Gudridge (de outro). O primeiro defendeu à época que fossem traçadas as linhas mestras para uma "Constituição de Emergência" com a identificação de medidas emergenciais de restrição a direitos fundamentais; os dois últimos, em contraponto, defenderam a não adoção de medidas de emergência restritivas, pois as linhas mestras de contenção do arbítrio já estavam desenhadas e demarcadas nas linhas da própria Carta Magna americana, numa "Constituição Anti-Emergência".

25 Assim: "[...] propostas relativas à maneira correta de interpretar uma determinada cláusula estatutária ou à maneira correta de resolver, de acordo com o direito existente, um conflito normativo. Tais propostas, embora preocupadas com o direito existente (e não com a forma como o direito deveria ser), pertencem, não obstante, ao domínio da concessão prática e da política jurídica..." Em: CHIASSONI, Pierluigi. Wiener Realism. Em: Luís Duarte d'Almeida; John Gardner; Leslie Green [edit.]. Kelsen Revisited: New Essays on the Pure Theory of Law. Oxford and Portland, Oregon: Hart Publishing, 2013, p. 152.

26 "Tomarei os seguintes como os oito princípios inerentes a uma jurisprudência realista: 1. Direito positivo como ideologia institucionalizada; 2. Direito natural como ideologia em busca de institucionalização; 3. Mutabilidade do direito; 4. Instrumentalidade dos direitos; 5 . Ceticismo de regras, discrição judicial, não cognitivismo interpretativo, ceticismo de fatos; 6 . falta de sistematicidade intrínseca do direito; 7 . Empirismo e não-cognitivismo meta-ético; 8. Epistemologia realista." Em: CHIASSONI, Pierluigi. Wiener Realism. Em: Luís Duarte d'Almeida; John Gardner; Leslie Green [edit.]. Kelsen Revisited: New Essays on the Pure Theory of Law. Oxford and Portland, Oregon: Hart Publishing, 2013, p. 134135.

27 CHIASSONI, Pierluigi. Wiener Realism. Em: Luís Duarte d'Almeida; John Gardner; Leslie Green [edit.]. Kelsen Revisited: New Essays on the Pure Theory of Law. Oxford and Portland, Oregon: Hart Publishing, 2013.

28 ACKERMAN, Bruce. The Emergency Constitution. The Yale Law Journal, v. 113, 2004

29 TRIBE, Laurence H.; GUDRIDGE, Patrick. The Anti-Emergency Constitution. The Yale Law Journal, v. 113, 2004. 
Com efeito, este é o cerne da controvérsia a ser enfrentada neste estudo. Numa proposta de diálogo a partir (e além) de posicionamentos aparentemente hegemônicos, buscam-se contrapontos antagônicos para, de alguma maneira, contribuir com o debate fora da zona de conforto de aderir a posicionamentos previamente dados e, muitas vezes, não muito bem refletidos. Para tanto, a liberdade é avaliada na perspectiva do significado de sua elevação à categoria de Direito Fundamental, bem como nos parâmetros igualmente constitucionais para a sua eventual restrição.

\section{O ESTADO DE LIBERDADE E O DIREITO}

A liberdade é como o ar que se respira. Não se pergunta o que é esse ar; não se perde tempo a discutir acerca dele, a argumentar sobre ele, a pensar nele. A menos que, por qualquer questão improvável, ele venha a faltar e, por algum motivo, não se consiga respirar. ${ }^{30}$ Diante das suas mais diversas acepções, a designação que pode ser atribuída à categoria liberdade é igualmente diversificada. Qualquer espécie de análise de tudo o que estivesse associado a ela conduziria a uma extensa (ou infindável) tarefa de cunho jurídico, social e moral. Por isso, a análise que aqui interessa é aquela alinhada às posições jurídicas fundamentais da liberdade. No âmbito da sociologia, Zygmunt Bauman ${ }^{31}$ esclarece que a liberdade parece relativamente pouco. No essencial da teoria social, as considerações quanto ao "condicionamento social" da liberdade são poucas, espaçadas e marginais. Por outro lado, existe muito interesse e observações profundas sobre as "coações sociais", as pressões, as influências, a força, a coerção e todos os fatores criados pelo homem, os quais foram responsabilizados por impedirem a liberdade de se manifestar. Conforme o autor ${ }^{32}$, para uma pessoa ser livre, tem de haver pelo menos duas. A liberdade pressupõe uma relação social, uma assimetria de condições sociais; essencialmente implica diferença social - presume e implica a presença de divisão social. Se ser livre significa poder ir seja para onde for (consultas aos dicionários normalmente ofertam essa concepção), significa também que há pessoas que estão presas às suas casas e a quem é negado o direito de se deslocar livremente.

A partir de uma apertada digressão histórica ${ }^{33}$, no universo espiritual e político da polis grega (séculos VII-IV a.C), o conceito de liberdade era verificado a partir da possibilidade de participação dos cidadãos na vida pública da cidade. No séc. V a.C, com Sócrates, a categoria sofre importante inflexão, convertendo-se em desafio ético ligado ao domínio de si próprio: "o homem só será livre se não for dominado por seus apetites e paixões". Na Idade Média (séc. V-XV), a liberdade (no Ocidente) recebeu forte influência teológica, em razão da acentuada presença da Igreja Católica

Inspirado em: BAUMAN, Zygmunt. A liberdade. Tradução de M. F. Gonçalves de Azevedo. Lisboa: Editorial Estampa, 1989, p. 9.

BAUMAN, Zygmunt. A liberdade. Tradução de M. F. Gonçalves de Azevedo. Lisboa: Editorial Estampa, 1989, p. 13.

BAUMAN, Zygmunt. A liberdade. Tradução de M. F. Gonçalves de Azevedo. Lisboa: Editorial Estampa, 1989, p. 21-22.

Construída a partir dos estudos de: MENDES, Alexandre Fabiano. Liberdade. In: BARRETO, Vicente de Paulo (Coord.). Dicionário de Filosofia do Direito. São Leopoldo/Rio de Janeiro: Editora Unisinos/Editora Renovar, 2006, p. 534-538. 
e do Cristianismo na Europa. A partir do séc. XIV, com o Renascimento e a consequente guinada do cenário político-cultural da Europa, retoma-se o conceito de liberdade política e afirma-se uma progressiva liberdade de pensamento. No séc. XVII, o conceito de liberdade atravessa os debates teóricos sobre a formação do Estado, sua legitimidade e função. O direito de liberdade formulado neste período reforça a ideia de que o Estado só pode intervir na liberdade individual mediante um devido processo legal. No séc. XVIII, o movimento filosófico-político do lluminismo preconizou a garantia das liberdades e dos direitos do cidadão, combatendo o autoritarismo estatal, e difundiu o modelo de uma libertação humana guiada pelos ditames da razão e da reflexão filosófica. ${ }^{34} \mathrm{O}$ nascimento dos direitos vitais passa a criar forma neste período com a inovação institucional do Estado de Direito, mas é a partir da constitucionalização de deveres públicos que os direitos naturais se tornam direitos positivos invioláveis, pois são esses deveres públicos, ou obrigações, que formam as garantias dos cidadãos. ${ }^{35}$ Essa primeira categoria de direitos protege, exatamente, a liberdade do indivíduo e, por isso, consiste na denominada "pretensão de resistência à intervenção estatal" - também chamada de direito de defesa -, pois limita as possibilidades de atuação do Estado na supressão ou limitação desse direito (chamada de proibição de interferência). ${ }^{36}$ No séc. XIX, consolidase o modelo liberal ao tempo em que surgem os paradigmas deterministas, os quais confrontam as teorias alinhadas à ideia de liberdade universal e abstrata. Conforme os deterministas, o ser humano não é plenamente livre, pois sofre interferência de determinações internas e/ou externas ${ }^{37}$. No séc. $X X$, o conceito de liberdade passa a ser problematizado de forma singular pelo existencialismo, a qual parte da premissa de que a existência humana precede sua essência. Um dos grandes expoentes dessa via de análise da liberdade é Jean Paul Sartre ${ }^{38}$ : "minha liberdade está perpetuamente em questão em meu ser; não se trata de uma qualidade sobreposta ou uma propriedade de minha natureza; é bem precisamente a textura de meu ser (...)".

Assim, a liberdade pertence à determinação do conceito de pessoa humana. Liberdade indica um determinado estado. As vítimas de um poder opressivo pedem, antes de mais nada, liberdade. Diante de um poder arbitrário, pedem justiça. Diante de um poder despótico, que seja ao mesmo tempo opressivo e arbitrário, a exigência de liberdade não pode se separar da exigência de justiça. ${ }^{39}$

$34 \quad$ Neste período, Thomas Hobbes propôs o sacrifício da liberdade sob o primado da coação. Conforme registra Norberto Bobbio, Hobbes foi um conservador, não um totalitário. O estado de perfeita liberdade é o estado de natureza. O estado civil não nasce para salvar a liberdade do indivíduo, mas para salvar o indivíduo da liberdade, já que esta o conduz à ruína. A liberdade de que fala Hobbes é, certamente, a liberdade do indivíduo em relação ao Estado, a liberdade que o indivíduo desfruta no silentium legis (Hobbes jamais teria ousado dizer, como o fará Hegel, que a "verdadeira" liberdade consiste na obediência às leis). Conduto, essa liberdade em relação ao Estado não é, para o indivíduo, um direito, e sim uma concessão do soberano, razão por que a maior ou menor extensão da mesma depende do arbítrio de quem detém o poder (Conforme: BOBBIO, Norberto. A teoria política de Hobbes. Thomas Hobbes. Tradução de C. Nelson Coutinho. Rio de Janeiro: Campus, 1991, p. 60).

35 FERRAJOLI, Luigi. Direito e Razão: teoria do garantismo penal. 2. ed. São Paulo: Ed. Revista dos Tribunais, 2006, p. 793.

36 DIMOULIS, Dimitri; MARTINS, Leonardo. Teoria geral dos direitos fundamentais. 5. ed. São Paulo: Atlas, 2014 , p. 50-51.

37 As principais vertentes deterministas são o biológico, o psicológico e o sociológico, não sendo incomum concepções deterministas que agregam todas esses modelos.

38 SARTRE, Jean Paul. O ser e o nada: ensaio de ontologia fenomenológica. Tradução: Paulo Perdigão. 6. ed. Rio de Janeiro: Vozes, 1998, p. 543.

39 BOBBIO, Norberto. Igualdade e Liberdade. Tradução de Carlos Nelson Coutinho. 3. ed. Rio de Janeiro: Ediouro, 1997 , p. 7. 
Pertence a liberdade ao grupo dos chamados Direitos Inatos do homem; direitos inerentes à condição humana e essenciais para a realização da personalidade ${ }^{40}$; direitos que assistem a determinada pessoa somente pelo fato de ela existir. ${ }^{41}$ Conforme Robert Alexy ${ }^{42}$, seu âmbito de aplicação parece ser quase ilimitado. Quase tudo aquilo que, a partir de algum ponto de vista, é considerado como bom ou desejável é associado ao conceito de liberdade. $E$ isso vale tanto para disputas filosóficas quanto para polêmicas políticas.

\section{DIREITO FUNDAMENTAL À LIBERDADE NA CRFB/88}

Com José Afonso da Silva, pode-se falar de uma "regra constitucional ôntica ${ }^{43}$ da liberdade", sendo certo que "regra constitucional ôntica é a estrutura de um ser constitucional" e, neste sentido, recordando que a democracia repousa sobre três pilares ou princípios fundamentais (princípio da maioria, princípio da igualdade e princípio da liberdade), também se torna relevante recordar que liberdade, no sentido constitucional, divide-se em liberdade interna (liberdade subjetiva, psicológica ou moral; ou, ainda, liberdade "do querer" ou liberdade metafísica); e liberdade externa (liberdade objetiva), também dividida em liberdade física, liberdade pessoal, liberdade civil, liberdade política e liberdade da precisão ${ }^{44}$. Para efeitos de reflexão sobre o tema, na perspectiva jusfilosófica do mesmo autor ${ }^{45}$, são de eficácia plena e aplicabilidade direta e imediata "porque o legislador deu normatividade suficiente aos interesses vinculados à matéria de que cogitam", não dependendo de legislação e nem de providência do Poder Público para serem aplicadas.

A liberdade de locomoção, também chamada de liberdade de ir e vir (e ficar), sempre foi uma figura central para o sistema das liberdades fundamentais, de tal sorte que se constitui em presença constante desde a fase inaugural do constitucionalismo. ${ }^{46} \mathrm{~A}$ partir da leitura do art. $5^{\circ}$, caput, da CRFB/88, pode-se verificar que o direito à liberdade assume papel de extrema relevância no rol dos direitos fundamentais, principalmente porque se outorga à liberdade e aos demais direitos ali consignados a garantia de sua inviolabilidade.

40 Ver: SILVA, José Afonso da. Curso de direito constitucional positivo. 20. ed. São Paulo: Malheiros, 2002 , p. 27 e ss

41 O Direito de Liberdade foi por Kant denominado Direito Inato: o direito absoluto dos Direitos Fundamentais (BOBBIO, Norberto. A era dos direitos. E-book. Trad. Carlos Nelson Coutinho; apres. Celso Lafer. Nova ed. Rio de Janeiro: Elsevier, 2004, paginação irregular (posição 625). 42 ALEXY, Robert. Teoria dos Direitos Fundamentais. Tradução de Virgílio Afonso da Silva. 2. Ed. São Paulo: Malheiros, 2015, p. 218.

43 Observa José Afonso da Silva: "ôntico é adjetivo de origem grega que se refere à estrutura do ser. Convenção ôntica é aquela que da origem a um ser. Agora se entende, as regras que dão a organização do jogo, as regras que dão estrutura à convenção para que o jogo exista, são regras ônticas, porque definem a própria existência do ser, como as que definem a estrutura, a forma do tabuleiro de xadrez ou a estrutura, a forma do campo de futebol, são regras que exprimem uma necessidade, no sentido de que são necessárias para que o jogo exista, porque criam o espaço em que o jogo deve realizar-se; por isso, como foi dito, são regras ônticas, regras que se expressam mediante o verbo ser". Cfr. SILVA, José Afonso da. Teoria do Conhecimento Constitucional. São Paulo: Malheiros, 2014 , p. 363.

44 SILVA, José Afonso da. Teoria do Conhecimento Constitucional. São Paulo: Malheiros, 2014, p. 466-483.

45 Conforme o autor: "Algumas normas podem caracterizar-se como de eficácia contida, mas sempre de aplicabilidade direta e imediata, caso em que a previsão de lei não significa que desta dependa sua eficácia e aplicabilidade, visto que tal lei não se destina a lhes integrar a eficácia (já que tem amplamente), mas visa a lhes restringir a plenitude desta, regulando os direitos subjetivos que delas decorrem para os indivíduos ou grupos”. Cfr. SILVA, José Afonso da. Teoria do Conhecimento Constitucional. São Paulo: Malheiros, 2014 , p. 482.

46 SARLET, Ingo Wolfgang. Curso de Direito Constitucional. In: SARLET, Ingo Wolfgang; MARINONI, Luis Guilherme; MITIDIERO Daniel (Org.). 6. ed. São Paulo, SP: Saraiva, 2017 (versão digital), posição 564. 
Violam a Constituição, portanto, normas que ordenam ou proíbem algo que uma norma de direito fundamental permite fazer ou deixar de fazer. Trata-se daquilo que Robert Alexy ${ }^{47}$ chama de "liberdade protegida": todas as liberdades fundamentais que existem em relação ao Estado são protegidas por determinado direito, o qual garante que este não crie embaraços ao titular da liberdade em fazer ou não aquilo que a Constituição lhe permite. Conforme se observa, é neste mesmo sentido que o art. 50, inciso II, da CRFB/88 prescreve "que ninguém será obrigado a fazer ou deixar de fazer algo, senão em virtude de lei".

No plano constitucional brasileiro, estão expressamente previstos, dentre outros, os seguintes direitos de liberdade: a) liberdade de locomoção (art. 50, XV); b) liberdade de pensamento (art. 50, IV); c) liberdade de consciência, crença e culto (art. 50, VI); d) liberdade de imprensa (art. 50, IX); e) liberdade de associação (XVII).

O dispositivo referente ao Direito de Locomoção tem no inciso XV do art. $5^{\circ}$ da CRFB/88 a seguinte redação: "é livre a locomoção no território nacional em tempo de paz, podendo qualquer pessoa, nos termos da lei, nele entrar, permanecer ou dele sair com seus bens"48. Nesse contexto, a liberdade de locomoção se verifica como figura central para o sistema das liberdades fundamentais ${ }^{49}$, inclusive se assegurando a utilização do remédio constitucional do habeas corpus em caso de sua violação, conforme art. $5^{\circ}$, LXVIII da CRFB $/ 88^{50}$.

É claro que a liberdade é um direito que não se revela ilimitado ou imune a intervenções restritivas. Porém, ainda que cientes de que a liberdade não é, em princípio, absoluta, mas sim juridicamente conformada e limitada, não se poderá recair no extremo oposto, qual seja, sustentar que liberdade não apenas é juridicamente limitada, mas até mesmo é tida como criada pelo aparelho regulamentador estatal. Na verdade, como Direito Inato que é a liberdade, já que o ser humano, por força de sua própria natureza e dignidade, é livre ${ }^{51}$, deve-se resistir à tese apresentada por Jürgen Schwabe 52 , no sentido de que toda e qualquer atuação dos particulares seja, em última análise, $47 \quad$ ALEXY, Robert. Teoria dos Direitos Fundamentais. Trad. Virgílio Afonso da Silva. 2. ed. São Paulo: Malheiros Editores, 2015, p. 233.

48 BRASIL. Constituição (1988). Constituição da República Federativa do Brasil. Brasília, DF: Senado Federal, 1988

49 SARLET, Ingo Wolfgang; MARINONI, Luiz Guilherme; MITIDIERO, Daniel. Curso de Direito Constitucional. São Paulo: Editora Revista dos Tribunais, 2012. p 470.

50 "[...] LXVIII - conceder-se-á habeas corpus sempre que alguém sofrer ou se achar ameaçado de sofrer violência ou coação em sua liberdade de locomoção, por ilegalidade ou abuso de poder". In: BRASIL. Constituição (1988). Constituição da República Federativa do Brasil. Brasília, DF: Senado Federal, 1988.

51 Aliás, neste ponto, importa anotar que a redação do art. $5^{\circ}, \mathrm{XV}$, da CRFB/88 traz norma de eficácia contida e aplicabilidade imediata por conter a expressão "nos termos da lei", ou seja, estando ausentes leis ulteriores que regulamentem a questão, sua aplicação será imediata, pois dependem de restrições previstas ou dependentes de regulamentação que limite a sua aplicabilidade (Conf.: SILVA, José Afonso da. Aplicabilidade das Normas Constitucionais. 3. ed. rev. ampl. atual. São Paulo: Malheiros Editores, 1998. p. 83). No mesmo sentido, o art. $5^{\circ}$, $\S 1^{\circ}$ da CRFB/88 prevê que as normas de direitos fundamentais possuem aplicação imediata, mas o referido preceito possui exceções, conforme o exemplo citado. Canotilho, neste ponto, anota que "(...) se esta ideia de aplicabilidade direta significa uma normatividade qualificada, nem sempre os direitos, liberdades e garantias dispensam a concretização através de entidades legiferantes. Por outras palavras: a aplicabilidade direta das normas consagradoras de direitos, liberdades e garantias não implica sempre, de forma automática, a transformação destes em direitos subjetivos, concretos e definitivos" (CANOTILHO, J.J. Gomes. Direito Constitucional e Teoria da Constituição. 7. ed. Coimbra: Almeidina, 2003, p. 438). Por fim, vale a assertiva trazida por Robert Alexy: “(...) toda ação (fazer ou não-fazer) é permitida, a não ser que seja proibida por meio de uma norma jurídica formal e materialmente compatível com a Constituição" (ALEXY, Robert. Teoria dos Direitos Fundamentais. Tradução de Vergílio Afonso da Silva. São Paulo: Malheiros, 2008, p. 234). 
decorrência de uma autorização ou não proibição do Estado. ${ }^{53}$ Mas sendo a liberdade de locomoção passível de limitações, em que circunstâncias ou condições poderia ela ser restringida?

Conforme registra Ingo Sarlet ${ }^{54}$, essas limitações ao direito de liberdade de locomoção decorrem da necessidade de salvaguardar outros direitos fundamentais ou mesmo bens jurídico-constitucionais, como é o caso do direito de propriedade, visto que a liberdade de locomoção não abrange o direito de livre ingresso na propriedade particular, notadamente em se tratando da residência de alguém, situação que chega a configurar ilícito penal ${ }^{55}$. Ainda, existem restrições fundadas e justificadas na necessidade de salvaguardar a saúde, a segurança e a ordem públicas, impondo-se a ressalva de que, em qualquer caso, a legitimidade constitucional de tais restrições está condicionada à satisfação das exigências da proporcionalidade e/ou da razoabilidade, já pelo fato de que, a teor do art. 5. ${ }^{\circ}$, LIV, da CRFB/88, ninguém será privado de sua liberdade sem o devido processo legal.

Desse modo, as possíveis limitações ao direito de liberdade de locomoção se justificam, tanto em razão da natureza da norma, quanto na medida em que a liberdade ultrapassar a esfera do indivíduo e passe a atingir a coletividade de forma negativa, sendo necessária a adoção de meios de restrição. Três são as possibilidades constitucionalmente previstas: a) flagrante delito; b) ordem escrita e fundamentada de autoridade judiciária competente; c) vigência de Estado de Sítio. ${ }^{56}$ As duas primeiras hipóteses estão previstas no art. $5^{\circ}, \mathrm{LXI}$, da CRFB $/ 88^{57}$; a terceira encontra previsão do art. 139, inciso I, do texto constitucional ${ }^{58}$. Nesta última situação, autoriza-se uma série de medidas que afetam diretamente a liberdade de locomoção dos indivíduos (obrigação de permanecer em local determinado e detenção em edifício não destinado a acusados ou condenados por crimes comuns), "mas em nenhum momento, mesmo na pendência de Estado de Sítio, a Constituição prevê a completa suspensão da liberdade de locomoção". Conforme Ingo Sarlet ${ }^{59}$, essas restrições cabíveis no caso de Estado de Sítio (que abrange a hipótese de um estado de guerra externa) são, todavia, excepcionais e se justificam apenas na vigência de tal Estado de Exceção.

53 SARLET, Ingo Wolfgang. Direitos Fundamentais e Direito Privado: algumas considerações em torno da vinculação dos particulares aos direitos fundamentais. In: . (Org.). A constituição concretizada. Porto Alegre: Livraria do Advogado, 2000. p. 136.

54 SARLET, Ingo Wolfgang. Curso de Direito Constitucional. In: SARLET, Ingo Wolfgang; MARINONI, Luis Guilherme; MITIDIERO Daniel (Org.). 6. ed. São Paulo, SP: Saraiva, 2017 (versão digital), posição 570.

55 Código Penal Brasileiro, Art. 150 - Entrar ou permanecer, clandestina ou astuciosamente, ou contra a vontade expressa ou tácita de quem de direito, em casa alheia ou em suas dependências: Pena - detenção, de um a três meses, ou multa. (...); CRFB/88, Art. $5^{\circ}, \mathrm{XI}$ : XI - a casa é asilo inviolável do indivíduo, ninguém nela podendo penetrar sem consentimento do morador, salvo em caso de flagrante delito ou desastre, ou para prestar socorro, ou, durante o dia, por determinação judicial; (...).

56 Há algumas exceções a essas três regras, também previstas no texto constitucional, a exemplo da restrição da liberdade do militar nos casos de transgressão militar ou crime propriamente militar, definidos em lei (conforme art. $5^{\circ}$, LXI, parte final).

$57 \mathrm{CRFB} / 88$, art. $5^{\circ}, \mathrm{LXI}$, ninguém será preso senão em flagrante delito ou por ordem escrita e fundamentada de autoridade judiciária competente (...).

58 Art. 139. Na vigência do Estado de sítio decretado com fundamento no art. 137, I, só poderão ser tomadas contra as pessoas as seguintes medidas: I - obrigação de permanência em localidade determinada [...]”. In: BRASIL. Constituição (1988). Constituição da República Federativa do Brasil. Brasília, DF: Senado Federal, 1988.

59 SARLET, Ingo Wolfgang. Curso de Direito Constitucional. In: SARLET, Ingo Wolfgang; MARINONI, Luis Guilherme; MITIDIERO Daniel (Org.). 6. ed. São Paulo, SP: Saraiva, 2017 (versão digital), posição 569. 
Tem-se, na liberdade de locomoção, aquilo que se entende por liberdade jurídica, no sentido de que a permissão no sentido de negação deve ser descrita na forma colocada por Hobbes: "nos casos nos quais o soberano não proscreveu nenhuma regra, o sujeito tem a liberdade de agir ou de se abster de acordo com a sua própria discricionariedade". Na medida em que permissões nada mais são do que a ausência de proibições ${ }^{60}$, a liberdade de locomoção pode ser usufruída sempre que não estiver presente qualquer das limitações constitucionais e/ou legais.

\section{A COVID-19 E AS RESTRIÇÕES NO ÂMBITO DA LIBERDADE DE LOCOMOÇÃO}

A pandemia do vírus SARS-CoV-2 tem provocado questões diversas sobre as medidas mais eficazes no seu enfrentamento, sobretudo porque deixa nua a fragilidade de postulados jurídicos afetados. No centro do problema ${ }^{61}$, a implementação de medidas de distanciamento social e de restrições à liberdade de locomoção das pessoas. Implementa-se, aqui, uma tensão entre a liberdade de locomoção e a segurança no que concerne aos controles sanitários considerados essenciais para se evitar a disseminação do vírus.

E essas medidas restritivas implantadas em razão do reconhecido estado de emergência ${ }^{62}$ têm provocado inquietações no âmbito teórico. Acerca do contexto italiano e na linha crítica às restrições aos direitos de liberdade, está Giorgio Agamben ${ }^{63}$ que, por exemplo, consignou considerar as medidas desproporcionais, sobretudo em razão de dois fatores. Primeiro, diante da crescente tendência da utilização do Estado de Exceção como técnica de governo ${ }^{64}$; depois, em razão da difusão de um "estado de medo" a justificar medidas restritivas de direitos em prol de uma maior segurança das pessoas.

$60 \quad$ Enunciado encontrado em August Thon a partir de Robert Alexy (ALEXY, Robert. Teoria dos Direitos Fundamentais. Trad. Virgílio Afonso da Silva. 2. ed. São Paulo: Malheiros Editores, 2015, p. 231).

61 Thomas V. Conti destaca uma "Crise Tripla do Covid-19": a) comportamental, consistente na exigência de rápida mudança de hábitos sociais Os hábitos que precisam ser mudados podem ir desde ações pequenas, como hábitos da higiene (lavar as mãos, formas de cumprimento); padrões maiores, como tamanho de eventos possíveis de serem realizados (festas, encontros sociais); até setores econômicos específicos em queda livre (hotelaria, turismo, casas noturnas). Também é uma crise no comportamento de governantes, pressionados por agilidade, transparência, comunicação verdadeira, decisões baseadas em evidências, corte de privilégios e de outros gastos supérfluos e redirecionamento de recursos; b) sanitária, que consiste na possibilidade real e provável do colapso do sistema de saúde de todos os países do mundo cuja velocidade de propagação do vírus não for reduzida rápida e substancialmente. Este risco extremamente provável de colapso aumentará a letalidade não apenas da Covid-19, mas também de todas as outras doenças e internações por conta da falta de leitos e profissionais de saúde. Adicionalmente, há o risco real de colapso do sistema funerário, podendo gerar cenas de terror e consequente desespero e caos social; e c) econômica, que se refere a todas as dificuldades econômicas impostas pela mudança de comportamentos, aumento da aversão ao risco, medo crescente conforme o sistema de saúde colapsa, queda do comércio e investimentos internacionais e possíveis problemas econômicos adicionais a depender de quais políticas públicas forem adotadas, e quando (Conf.: CONTI, Thomas V. Crise Tripla do Covid-19: um olhar econômico sobre políticas públicas de combate à pandemia. Disponível em: http://thomasvconti.com.br/pubs/coronavirus/ Acesso em: 18 jun. 2020).

62 Ver: PÉREZ TAPIAS, José Antônio. Entre o risco e o medo, a biopolítica em alta. Instituto Humanitas UNISINOS, 17 mar. 2020. Disponível em: http://www.ihu.unisinos.br/78-noticias/597147-entre-o-risco-e-o-medo-a-biopolitica-em-alta. Acesso em: 20 jun. 2020.

63 AGAMBEN, Giorgio. O Estado de Exceção provocado por uma emergência imotivada. Tradução de Luisa Rabolini. Instituto Humanitas UNISINOS, 26 fev. 2020a. Disponível em: http://www.ihu.unisinos.br/78-noticias/596584-o-estado-de-excecao-provocado-por-umaemergencia-imotivada. Acesso em: 22 jul. 2020.

64 Essa tendência foi mais bem diagnosticada pelo autor na obra: AGAMBEN, Giorgio. Estado de Excepção. Tradução de Miguel Freitas da Costa. Lisboa: Edições 70, 2010. 
De forma semelhante, Raúl Zibechi65 registrou que é necessário voltar aos períodos do nazismo e do estalinismo, há quase um século, para encontrar exemplos de controle de população tão extenso e intenso como os que aconteceram na China, quando verificado o contexto pandêmico da doença, sob o "pretexto" do coronavírus. Há um gigantesco pan-óptico militar e sanitário, que limita a população a viver trancada e sob permanente vigilância. O autor considera que se está diante de um ensaio que será aplicado em situações críticas futuras, como desastres naturais, tsunamis e terremotos, mas, sobretudo, diante das grandes convulsões sociais capazes de provocar devastadoras crises políticas para "os de cima". De acordo com Zibechi, eles se preparam para eventuais desafios à sua dominação. Conforme se verifica, esses autores interpretam essas medidas restritivas como meros exercícios de poder de controle do Estado, considerando-as desproporcionais para tratar de uma ameaça que se apresenta. Agamben ${ }^{66}$ diz que, depois que o terrorismo foi esgotado como justificativa para medidas excepcionais, a invenção de uma epidemia poderia oferecer o pretexto ideal para expandir essas medidas para além de qualquer limite. A segunda razão seria "o estado de medo que nos anos recentes tem sido difundido na consciência individual e que se traduz em uma necessidade real por estados de pânico coletivo, nos quais a epidemia uma vez mais oferece o pretexto ideal". ${ }^{67}$

Slavoj Žižek ${ }^{68}$ reconhece que Agamben descreve um aspecto importante do funcionamento do controle estatal nas epidemias em andamento. No entanto, algumas perguntas parecem não ter resposta na análise do filósofo italiano: por que é que o poder estatal estaria interessado em promover esse pânico, que é acompanhado por desconfiança no próprio poder estatal e que perturba a reprodução normal do capital?

É realmente do interesse do capital e do poder estatal desencadear uma crise econômica global para revigorar seu reinado? São claros os sinais de que não apenas as pessoas comuns, mas também os poderes estatais, estão em pânico, plenamente conscientes de não serem capazes de controlar a situação. Mas seria isso tudo apenas um estratagema?

65 ZIBECHI, Raúl. Coronavírus: a militarização das crises. In: DAVIS, Mike, et al.: Coronavírus e a luta de classes. Terra sem Amos: Brasil, 2020, p. 31-33.

66 Vale registrar que esse texto foi publicado, originariamente, na última semana de fevereiro de 2020, antes, portanto, de a Organização Mundial da Saúde (OMS) reconhecer o contexto pandêmico do vírus.

67 AGAMBEN, Giorgio. O estado de exceção provocado por uma emergência imotivada. Disponível em: http://www.ihu.unisinos.br/78noticias/596584-o-estado-de-excecao-provocado-por-uma-emergencia-imotivada. Acesso em: 22 jul. 2020.

68 ŽIŽEK, Slavoj. Monitorar e Punir? Sim, por favor! Tradução de Leonardo Mendonça. Publicado em 16 de março de 2020. Disponível em: https://thephilosophicalsalon.com/monitor-and-punish-yes-please/. Acesso em: 28 jul. 2020. 
O fato é que essa interpretação social não faz desaparecer a realidade da ameaça. Por isso, possivelmente há uma aderência a uma disciplina rigorosa sobre restrições da liberdade ambulatorial que seja necessária, na medida em que oferece apoio e proteção fundamental a todos aqueles que estão mais expostos: todos os profissionais de saúde, é claro, que estão diretamente na linha de frente de combate ao vírus, e que devem poder contar com uma disciplina firme, especialmente, por parte dos infectados. Mas, também, aos fisicamente mais frágeis, como os idosos, especialmente os que estão em asilos; assim como todos aqueles que precisam, necessariamente, trabalhar e correr o risco de contágio. Neste ponto, uma reflexão trazida por Alain Badiou69 é importante: "a disciplina daqueles que podem obedecer ao imperativo 'fiquem em casa' também deve encontrar e propor meios para aqueles que mal têm um "lar" ou nenhum, para que possam, mesmo assim, encontrar um abrigo seguro".

\subsection{RESTRIÇÃOÀLIBERDADEDELOCOMOÇÃO NOBRASILPORDETERMINAÇÃO DE GOVERNOS LOCAIS}

No Brasil, as relações institucionais estão pautadas dentro de um padrão organizacional em que se encontram dois ambientes: a) o de legalidade ordinária, em que cada poder exerce suas atribuições conforme a constituição e os direitos e garantias fundamentais são protegidos; b) o de legalidade extraordinária, que acontece quando há, em regra, uma hipertrofia do Poder Executivo e no qual há restrição de direitos e suspensão de garantias dos cidadãos. Neste segundo caso, duas espécies de medidas são previstas no texto constitucional que seja possível o Poder Executivo responder à crise que se apresente, notadamente, com a supressão de direitos e garantias que não seriam possíveis, legitimamente, no âmbito da legalidade ordinária. A primeira é o Estado de Defesa (menos invasiva e prevista no artigo 136); a segunda, o Estado de Sítio (mais invasiva e prevista nos artigos 137,138 e 139). ${ }^{70}$

De fato, o Estado de Sítio, conforme verificado, só é possível em dois casos bem específicos: a) comoção grave de repercussão nacional ou ocorrência de fatos que comprovem a ineficácia de medida tomada durante o Estado de Defesa; b) declaração de estado de guerra ou resposta à agressão armada estrangeira. ${ }^{71}$

69 BADIOU, Alain. Sobre a situação epidêmica. In: DAVIS, Mike, et al.: Coronavírus e a luta de classes. Terra sem Amos: Brasil, 2020 , p. 36.

70 TAVARES, Marcelo Leonardo. A restrição à liberdade e o Conselho da República em época de coronavírus. Disponível em: < https://www. conjur.com.br/2020-mai-01/marcelo-tavares-restricao-liberdade-conselho-republica>. Acesso em: 20 jul. 2020.

71 Conforme redação do art. 137 da CRFB/88. 
Assim, de acordo com aquilo que se observa, a crise sanitária provocada pela pandemia do novo coronavírus não se encaixa em nenhuma dessas hipóteses constitucionalmente previstas. Diante disso, em 06 de fevereiro de 2020, entra em vigor a Lei Federal 13.979/202072, quando passa a vigorar, também, outros instrumentos disciplinadores do Poder Executivo Federal que regulamentam possíveis medidas restritivas no âmbito da emergência instalada pela pandemia da Covid-19, dentre as quais, a Portaria n. 356/2020/GM/MS e a Portaria Interministerial n. 5/2020/MS/MJSP.

No entanto, numa leitura confusa da Lei 13.979/2020 e apostando em técnicas de isolamento social como mecanismo de redução de propagação do vírus, governos locais (Estados e Municípios) passaram a instituir, ainda que em plano temporário, medidas do confinamento absoluto (lockdown) ${ }^{73}$, emitindo-se determinações de bloqueio total de determinadas regiões, bairros ou cidades (restrição genérica de acesso ao seu território) ${ }^{74}$, além de "toques de recolher"75 e também fechamento e interdição de vias federais e estaduais.

Lenio Streck aborda exatamente este problema de limitação de direitos fundamentais no momento da grave crise pandêmica provocada pela Covid-19. Para tanto, faz referência ao texto de Tom Ginsburg ${ }^{76}$ em perspetiva comparativa com mais de 150 países e as medidas para contenção do vírus adotadas nesses locais. Nas palavras de Streck, o modelo de restrição dos espaços de liberdade ambulatorial pela via de decretos/portarias de governos locais adotado pelo Estado Brasileiro é correto.

72 Dentre as medidas previstas no art. $3^{\circ}$, destacam-se aquelas dos incisos I e II: isolamento e quarentena, respectivamente. $\mathrm{O}$ art. $2^{\circ}$, I, traz o conceito legal de "isolamento": "separação de pessoas doentes ou contaminadas, ou de bagagens, meios de transporte, mercadorias ou encomendas postais afetadas, de outros, de maneira a evitar a contaminação ou a propagação do coronavírus; (...)". O inciso II do mesmo artigo traz o conceito para a categoria "quarentena": "restrição de atividades ou separação de pessoas suspeitas de contaminação das pessoas que não estejam doentes, ou de bagagens, contêineres, animais, meios de transporte ou mercadorias suspeitos de contaminação, de maneira a evitar a possível contaminação ou a propagação do coronavírus".

73 No mês de maio de 2020, os Estados do Maranhão, Ceará e Pará adotaram essa técnica.

74 Ver matéria publicada em 02 de julho de 2020 no "G1 - Minas": "Para frear chegada do coronavírus, Prefeitura de Tiradentes fecha a cidade para os turistas". Disponível em: https://g1.globo.com/mg/minas-gerais/noticia/2020/07/02/covid-19-prefeitura-de-tiradentes-fecha-cidadepara-turismo.ghtml. Acesso em: 25 jul. 2020.

75 Notícia do periódico "Correio", de 24 de junho de 2020: "Mais 22 cidades baianas terão toque de recolher estabelecido pelo estado". Disponível em: https://www.correio24horas.com.br/noticia/nid/mais-22-cidades-baianas-terao-toque-de-recolher-estabelecido-pelo-estado/. Acesso e: 25 jul. 2020.

76 GINSBURG, Tom; VERSTEEG, Mila. Covid-19: States of Emergencies: Part I and Part II. Blog Harvard Law Review, de 17 e 20 de abril de 2020. 
Trata-se, conforme artigo publicado pelo autor em coautoria com Pedro Serrano ${ }^{77}$, uma espécie de "legalidade extraordinária"78. Na perspectiva dos autores, não se trataria, pois, de um Estado de Exceção. Conforme se verifica do texto, o fundamento central para este posicionamento é o argumento de que os direitos não seriam absolutos, sobretudo porque o texto constitucional não poderia prever todos os casos. Inclusive, permite-se a posterior judicialização em caso de eventuais abusos.

77 STRECK, Lenio. OPINIÃO Lockdown e Estado de Sítio: operar uma unha não exige anestesia geral! Conjur de 11 de maio de 2020; SERRANO, Pedro. É a ciência, estúpido! Carta Capital de 20 de maio de 2020.

78 Em suas palavras, proferidas no webinário "Constituição em tempos de crise: até onde vai a força do texto?", do qual também participaram o min. Gilmar Mendes (STF), Cristina Peduzzi (Presidente do TST), Paulo Mota Pinto e Otavio Luiz Rodrigues Jr, mencionou o professor Lenio Streck: "Eu tenho uma posição bem ortodoxa sobre isso. Óbvio, há uma diferença entre o Estado de Exceção, que é um conceito político, e o que Pedro Serrano e eu chamamos de "legalidade extraordinária", mas eu andei fazendo uma pesquisa pelo mundo e encontrei bons textos sobre isso, e um texto do Tom Ginsburg na revista de Harvard sobre o modo como os países estão lidando com isso. E uma luta contra a Covid levou esses países, inclusive as democracias liberais, a tomarem medidas extraordinárias, que poderiam ser constitucionalmente problemáticas. Então testemunhamos países inteiros sendo bloqueados, com vigilância em massa a telefones celulares, serviços religiosos suspensos, viagens restritas, toques de recolher, militares, etc. Isso liga um alarme né? Se poderia levar a uma deterioração das liberdades civis e da democracia constitucional à longo prazo. Os professores fizeram uma pesquisa em cento e cinquenta e tantos países e mostraram que existem 3 bases legais para as medidas da Covid nesse período todo. A primeira é o modo de declaração de um estado de emergência sob a Constituição. Isso hoje, mais de $90 \%$ das Constituições do mundo possuem cláusulas de algum modo. E $56 \%$ das Constituições exige que o parlamento aprove. O segundo modo é a legislação existente que trata da saúde pública em desastres nacionais, e essa questão é uma maneira de conceder poderes extraordinários ao governo, e, uma das maneiras é ativar a legislação extraordinária, que é destinada a lidar, por exemplo, com uma emergência sanitária. É amplamente aceito pela maioria que os direitos constitucionais não são absolutos, e que eles podem ser restringidos. Bom, eu não posso matar, e também durante a Pandemia não posso fazer algumas coisas, então, como os direitos nunca são absolutos, pode não ser necessário declarar uma emergência constitucional. O governo pode combater as crises por Lei, desde que quaisquer restrições às liberdades sejam necessárias e proporcionais. É o que se chama de modelo legislativo: garante o envolvimento legislativo no enfrentamento da crise. E talvez, mais importante, como quadro constitucional comum permanece em vigor, as restrições aos direitos permanecem sujeitas à revisão judicial. Isso me parece fundamental. Então, em vez de suspender alguns direitos fundamentais por meio de uma declaração de emergência, um grupo de países pode optar por limitar os direitos por meio de cláusulas de limitação comum consagradas nas Constituições. Neste sentido, Áustria, Dinamarca, Burkina Fasso, Noruega, Holanda, Taiwan, Japão e Suíça usam esse tipo de legislação para impor medidas contra o coronavírus. O terceiro modelo é a nova legislação de emergência. Então, em outros países, as legislaturas aprovaram novas Leis que delegam os poderes especiais executivos para lidar com a Covid. Essa nova legislação pode ser necessária quando as leis existentes não autorizam o tipo de poderes necessários para combater a epidemia. O Brasil me parece que adotou exatamente o modelo misto, que Pedro Serrano e eu chamamos de legalidade extraordinária, que é um misto entre o modelo legislativo e este terceiro modelo, que chamaríamos então de legalidade extraordinária. Obviamente que não é Estado de Exceção. Então, nesse sentido, nesse confronto, se tiraria logo fora essa discussão do Estado de Exceção como conceito político, etc., e eu, nesse sentido, recuso a discussão do velho dualismo metodológico entre a realidade social e a realidade normativa. A legislação da Constituição e a legislação infraconstitucional e a que está sendo feita, e as decisões do Supremo (que também são norma), elas conseguem fazer com que não precisemos partir para fora dos limites constitucionais, tampouco da letra daquilo que a gente poderia chamar de limites semânticos. Então, há leis já aprovadas pelo legislativo. O próprio Supremo já disse que Estados e Municípios podem fazer determinadas questões como a delimitação de saídas para preservação e não contaminação dos demais, esse me parece, então, o modo de dizer que a Constituição [ela] resiste, que a Constituição não demanda uma reforma constitucional. A Constituição, se nós examinarmos a história toda, nós veremos que a própria Medida Provisória já é algo previsto pela própria Constituição, que é uma medida de estado de necessidade. Aliás, relevância e urgência, o Ministro Gilmar acabou de falar sobre a questão da Intervenção Federal, todos esses detalhes são questões que estão postas e que hoje são usadas. E vou mais longe. O Código Civil napoleônico já previa que, como a lei não pode prever tudo e as constituições também não podem prever tudo, previa-se ali que o juiz não pode deixar de julgar sobre o pretexto de lacunas. Isso já era a questão [posta] de que pode haver uma crise e faltar previsões e a Constituição também, só que a Constituição, depois do segundo pós-guerra, ela cria uma espécie de quarto do pânico, porque ela desconfia de si mesma, ela desconfia dos juristas, e, pra isso, ela por dentro dela mesma, algumas possibilidades, como Medida Provisória, emenda constitucional (...) Não é necessário nem o Estado de Defesa, e nós estamos atravessando esse período sem Estado de Defesa e sem Estado de Sítio. E vou mais longe, o famoso art. 148 da Constituição de Weimar, nem ali estava previsto que se poderia mexer em direitos sociais durante o Estado de Defesa ou no Estado de Exceção. Bom, no Brasil também. Tanto no Estado de Defesa quanto no Estado de Sítio, não podemos provocar retrocessos sociais, digamos, fora dos limites da Constituição, e, quando a Constituição diz que se pode reduzir salários, essa redução de salários pode ser feita a partir de um acordo. (...) Veja que na própria Constituição é possível estabelecer os Estados de Exceção. Eu preciso de algo para resolver um problema, o Supremo resolveu com uma liminar do Ministro Alexandre de Moraes. Noutra decisão, o Supremo deu, dizendo que os Sindicatos não precisam fazer assinatura, (...) neste sentido, eu sou um otimista e um ortodoxo constitucional. Penso que não precisamos de em nenhum momento fazer uso de medidas de exceção, e recuso, obviamente, e de pronto, a frase que foi dita pelo ministro Fux, outro dia num artigo, citando Santo Augustinho de que "na necessidade não há Lei". Eu faria o inverso. É na necessidade que nós precisamos da Lei, e é na necessidade que nós testamos se nós estamos acostumados a jogar dentro das regras do jogo. Não sair é o grande desafio, porque quando se sai, é difícil voltar". Cfr. Disponível em: <https://www.youtube.com/watch?v=55wAfLkuug Y\&feature=youtu.be>, acesso em 7 de agosto de 2020. 
O momento exige muitas reflexões, avessas a "terraplanismos jurídicos", como a necessária respeitabilidade e confiança nos órgãos internacionais de saúde (OMS) e outros posicionamentos com consenso mínimo para preservação de vidas. Esta pesquisa, aliás, não questiona a necessidade de adoção de medidas, todas de fato muito importantes e com assento e sede constitucional para proteção da dignidade humana e o direito à saúde, como aliás se exige de quem trate do tema sob qualquer aspecto.

Também não se questiona aqui a decisão do Supremo Tribunal Federal sobre a competência concorrente entre União, Estados e Municípios no que se relaciona à tomada de providências sobre as medidas de proteção à saúde, à vida e as medidas de combate ao Covid-19. Antes, observa-se que o próprio Supremo Tribunal Federal, por meio de vários de seus ministros, estabeleceu que a concorrência da competência entre os diversos entes federados não exime nenhum deles de tomada de providências, pois o que se verificou foi o gestor do governo federal e muitos gestores de governos estaduais pautando o discurso político no sentido de uma não adoção de providências mais drásticas de combate ao vírus e, do outro lado, alguns gestores de estados e municípios pautando o discurso político em sentido diverso, num verdadeiro "jogo de empurra".

\subsection{A PROPORCIONALIDADE COMO MEDIDA DE ANÁLISE CONSTITUCIONAL79}

\subsubsection{Proporcionalidade EM Geral}

Nesta parte do trabalho, analisam-se os argumentos utilizados para sustentar a restrição ao direito fundamental à liberdade (lockdown e restrição de vias terrestres sem base na Lei) ao crivo do "teste da proporcionalidade" (na versão proposta por Matthias Klatt ${ }^{80}$, famoso discípulo de Robert Alexy).

Antes disso, é importante registrar que se pode compreender o emprego do princípio da proporcionalidade, ao menos, de duas maneiras: 1) utilização do princípio da proporcionalidade pelo Supremo Tribunal Federal; e 2) submissão de decisões ao "teste da proporcionalidade".

Com relação à primeira forma, observam-se duas importantes pesquisas, uma a nível de mestrado, outra de doutoramento. De autoria de Paola Cantarini ${ }^{81}$ e sob a orientação de Willis Santiago

\footnotetext{
79 Parcialmente beneficiado de texto anterior de um dos autores sobre o tema do teste da proporcionalidade em Matthias Klatt. Cfr. PÁDUA, Thiago Aguiar; RODRIGUES DE PAULA, Lucas. O "Museu de Cera" das Ideias Constitucionais: a mudança de entendimento do STF sobre o processo de Governadores por crime comum, sem autorização legislativa, submetida ao "teste da proporcionalidade" de Matthias Klatt. Cadernos de Direito v. 1, n. 1, 2019.

80 KLATT, Matthias; MEISTER, Moritz. Proportionality - a benefit to human rights? Remarks on the ICON controversy. International Journal of Constitutional Law $n^{\circ} 10,2012$; KLATT, Matthias; MEISTER, Moritz. La Proporcionalidad como principio constitucional universal. México: UNAM, 2017; KLATT, Matthias; MEISTER, Moritz. A proporcionalidade como princípio constitucional universal. Revista Publicum, n. 1, 2015; KLATT, Matthias. A Máxima da Proporcionalidade: um elemento estrutural do constitucionalismo global. Trad. João Costa Neto. Observatório da Jurisdição Constitucional. Ano 7, n. 1, 2014; KLATT, Matthias. Argumentação jurídica e devido processo legal. Trad. Luiza A. B. Borges. Em: TOLEDO, Claudia. O pensamento de Robert Alexy como sistema. Rio de Janeiro: Forense, 2017KLATT, Matthias; MEISTER, Moritz. The Constitutional Structure of Proportionality. Oxford, 2012.

81 CANTARINI, Paola. Direito comercial à luz do princípio da proporcionalidade: Uma análise filosófico-poética. Novas Edições, 2015.
} 
Guerra Filho, a primeira maneira registra a fragilidade da utilização da proporcionalidade pelo STF, que utiliza muitas vezes indistintamente os princípios da razoabilidade e da proporcionalidade, ora utilizando proporcionalidade como sinônimo de "equidade", ora empregando apenas uma parte do princípio (apenas um de seus "fragmentos", ou subprincípios); de outra parte, a abordagem anotada na tese é de autoria de Fausto Santos de Morais, trabalho que fora produzido no PPG/Direito da UNISINOS, sob a supervisão do professor Lenio Luiz Streck. Este último analisa o comportamento do STF num período de 10 anos (entre 07/07/2002 e 07/07/2012) com 189 decisões prolatadas a partir do princípio da proporcionalidade. Do estudo, constata-se que o STF utiliza de forma equivocada o (apenas a vulgata do) pensamento alexyano quando se trata do princípio da proporcionalidade ${ }^{82}$.

No que se refere à segunda hipótese, uma das decisões do Tribunal é analisada a partir de um determinado ponto de vista que busque estabelecer seu acerto (ou equívoco), tendo como paradigma (exemplo de contraste) o próprio princípio da proporcionalidade e seus aspectos mais visíveis. E é exatamente este o âmbito de análise desta parte deste artigo. Pois bem. O princípio da proporcionalidade é algo controverso, sendo certo que, a despeito disso, tem seu nascimento por ocasião do famoso julgamento da Corte Constitucional Alemã (Apothekenurteil; BVerfGE 7, 377), de 1958, o qual é considerado o caso de maior sucesso de um "transplante de ideias" a partir da difusão de sua utilização por grande parte dos Tribunais ao redor do mundo. Willis Santiago Guerra Filho e Paola Cantarini, responsáveis pelo verbete "proporcionalidade" da "Enciclopédia Jurídica", destacam haver três contextos: 1) histórico; 2) teórico; e 3) de aplicação, considerado aqui o "princípio dos princípios", referente à "relatividade" mútua (verhältnismäfig), capaz de dar um "salto hierárquico" (hierarchical loop). Conforme o pioneiro estudo de Willis Santiago Guerra Filho, a proporcionalidade vai do topo da pirâmide normativa para sua base, pois valida (ou invalida) as normas individuais ali produzidas (administrativas, judiciais, etc.).

De maneira bastante concreta, observa-se que é o princípio da proporcionalidade que permite a realização daquilo que os norte-americanos denominam de "balancing" (entre interesses e bens), e cuja mesma ideia está na base alemã da "Abwägung" (sopesamento, ponderação). Por meio do princípio da proporcionalidade, busca-se preservar ao máximo os demais princípios em disputa, sem Ihes ferir o "núcleo essencial", local "onde se encontra entronizado o valor da dignidade humana, princípio fundamental e 'axial' do contemporâneo Estado Democrático", a partir do que é ele dividido em três subprincípios ou proposições parciais (Teilgrundsätze): a) "princípio da proporcionalidade em sentido estrito" ou "máxima do sopesamento" (Abwägungsgebot); b) "princípio da adequação"; e c) "princípio da exigibilidade" ou "máxima do meio mais suave" (Gebot des mildesten Mittels) ${ }^{83}$, aqui

82 MORAIS, Fausto Santos de. Hermenêutica e pretensão de correção: uma revisão crítica da aplicação do princípio da proporcionalidade pelo Supremo Tribunal Federal. São Leopoldo: UNISINOS, 2013.

83 Aliás, conforme ressaltado por Willis Guerra e Paola Cantarini, embora não esteja expresso no ordenamento jurídico brasileiro, o princípio da proporcionalidade "é uma exigência inafastável da própria fórmula política adotada por nosso constituinte, a do "Estado Democrático de Direito", pois sem a sua utilização não se concebe como bem realizar o mandamento básico dessa fórmula, de respeito simultâneo dos interesses individuais, coletivos e públicos". Cfr. GUERRA FILHO, Willis Santiago; CANTARINI, Paola. Proporcionalidade. Enciclopédia Jurídica da PUC-SP, Tomo de Teoria Geral e Filosofia do Direito, São Paulo, 2017. 
mencionados com certa frequência como adequação, necessidade e proporcionalidade em sentido estrito. Numa análise à posição de Virgílio Afonso da Silva ${ }^{84}$ acerca da distinção entre o princípio da proporcionalidade e o princípio da razoabilidade, Willis Santiago Guerra Filho e Paola Cantarini concordam em estabelecer que o princípio da (não)razoabilidade seria uma proibição do absurdo em direito, do que é "despropositado, daquilo que não tem finalidade juridicamente justificável. De outra parte, o da proporcionalidade se traduz em uma proibição de excessos e se presta a determinar o meio mais adequado, exigível e respeitoso à dignidade humana, para que se atinja certa finalidade, considerada merecedora de ser atingida, por razoável"85. Em outras palavras, por não ser absurdo e com respeito à proibição de excessos.

Existem muitas críticas ao princípio da proporcionalidade, tal como aquela apresentada por Stavros Tsakyrakis ${ }^{86}$, o qual sustenta que referido princípio é "obscuro" ou que "obscurece debates importantes". Há, ainda, aquela mais famosa no direito brasileiro e oferecida judicialmente no STF por parte do então Ministro Eros Roberto Grau, nos autos do Habeas Corpus n. 95.009/SP, quando disse que os princípios são banalizados, especialmente o da proporcionalidade, pois manipulado e inserido num patamar (e num contexto) argumentativo de que "não existiriam direitos absolutos", e assim sendo, a proporcionalidade seria utilizada como uma "gazua" (chave micha) apta a "arrombar toda e qualquer garantia constitucional". Aliás, o Ministro Eros Grau já havia se pronunciado de maneira provocativa sobre os limites dos tribunais quando abordou, em voto, a tese de Loewenstein sobre "as árvores judiciais que (não) tocam o céu" na Reclamação 4.335/AC.

\subsubsection{Proporcionalidade em Matthias Klatt}

Sem endossar a argumentação de que o princípio da proporcionalidade é uma varinha mágica de condão, e conscientes de que existem muitos problemas e críticas relevantes, para os fins deste texto, observa-se com Matthias Klatt que "a proporcionalidade é o melhor método para solucionar racionalmente colisões entre os objetivos de princípios contrapostos" e que "as etapas de aferição da adequação e da necessidade se referem à otimização em face das circunstâncias fáticas do caso concreto". Aqui, cinco passos são considerados: I) objetivo legítimo; II) meio legítimo; III) adequação; IV) necessidade; e V) sopesamento [ou ponderação] ${ }^{87}$.

Sobre o n. I (objetivo legítimo), num primeiro momento, conforme assevera Matthias Klatt, "a autoridade estatal que interfere em direitos de liberdade deve perseguir um objetivo legítimo com essa interferência". Para tanto, por primeiro, deve a autoridade estabelecer com precisão qual é o

84 AFONSO DA SILVA, Virgílio. O Proporcional e o Razoável. In: Revista dos Tribunais, vol. 798, 2002, p. 26.

85 GUERRA FILHO, Willis Santiago; CANTARINI, Paola. Proporcionalidade. Enciclopédia Jurídica da PUC-SP, Tomo de Teoria Geral e Filosofia do Direito, São Paulo, 2017.

86 TSAKYRAKIS, Stavros. Proportionality: An assault on human rights? 7 I NT ' L J. C ONST. L. (I·CON) 468 2009.

87 KLATT, Matthias. A Máxima da Proporcionalidade: um elemento estrutural do constitucionalismo global. Trad. João Costa Neto. Observatório da Jurisdição Constitucional. Ano 7, n. 1, 2014. 
objetivo perseguido com a interferência e se há ligação com o suporte fático concreto (Sachverhalt). Num segundo momento, é de se formular a pergunta: "este objetivo é juridicamente admissível? "Ressalta-se, neste ponto, existir dois tipos de objetivos legítimos: (a) os que traduzem "valores coletivos absolutos" (imposição obrigatória ao Estado); e (b) os que traduzem valores coletivos relativos (liberalidade que faculta ao Estado). ${ }^{88}$

A seu turno, sobre o $\mathrm{n}^{\circ}$. II (meio legítimo), "o meio efetivamente empregado deve ser precisamente designado e juridicamente avaliado", geralmente relacionado "a uma norma permissiva cuja consequência jurídica autoriza, em princípio, o emprego justamente do meio utilizado". Para este passo, um bom exemplo é a utilização da pena de morte (meio) para perseguir um objetivo legítimo (redução dos custos da execução penal), meio que seria vedado. ${ }^{89}$

Com relação ao passo n III (adequação), "um meio [será] adequado quando, com o seu auxílio, o objetivo perseguido pode ser fomentado. O objetivo não precisa ser completamente satisfeito por meio do emprego do meio; um fomento [seria] suficiente". Um outro bom exemplo é fornecido pelo autor: uma lei regulamentadora de caça com falcão que exigisse prova da habilidade com armas de fogo não seria adequada, pois "conhecimentos técnicos referentes a armas são irrelevantes para o exercício da falcoaria - caça que ocorre com a ajuda de uma ave de rapina - e, portanto, inadequados para o fomento do objetivo de exercer a caça de maneira mais ordenada"90.

Por sua vez, sobre o passo nº IV (necessidade), tem-se que "um meio [será] necessário, se não há outro meio igualmente adequado que interfira de maneira menos intensa no direito fundamental". Em um momento inicial, o "meio efetivamente empregado deve fomentar ou promover o objetivo almejado, no mínimo, na mesma medida em que o teria feito o meio alternativo", e num segundo momento, o meio efetivamente utilizado pode levar, "no máximo, a uma interferência tão intensa sobre o princípio constitucional restringido quanto o emprego - hipotético - do meio alternativo" 91.

Isso equivale a dizer que é necessário "determinar e - conforme o caso - comparar os efeitos do meio alternativo hipotético e do meio efetivamente empregado, tanto no que se refere à persecução do objetivo legítimo quanto à restrição do princípio constitucional"92.

$88 \quad$ KLATT, Matthias. A Máxima da Proporcionalidade: um elemento estrutural do constitucionalismo global. Trad. João Costa Neto. Observatório da Jurisdição Constitucional. Ano 7, n. 1, 2014.

89 KLATT, Matthias. A Máxima da Proporcionalidade: um elemento estrutural do constitucionalismo global. Trad. João Costa Neto. Observatório da Jurisdição Constitucional. Ano 7, n. 1, 2014.

90 KLATT, Matthias. A Máxima da Proporcionalidade: um elemento estrutural do constitucionalismo global. Trad. João Costa Neto. Observatório da Jurisdição Constitucional. Ano 7, n. 1, 2014.

91 KLATT, Matthias. A Máxima da Proporcionalidade: um elemento estrutural do constitucionalismo global. Trad. João Costa Neto. Observatório da Jurisdição Constitucional. Ano 7, n. 1, 2014.

92 KLATT, Matthias. A Máxima da Proporcionalidade: um elemento estrutural do constitucionalismo global. Trad. João Costa Neto. Observatório da Jurisdição Constitucional. Ano 7, n. 1, 2014. 
Finalmente, o passo $\mathrm{n}^{\circ} \mathrm{V}$ (sopesamento, ponderação ou proporcionalidade em sentido estrito) representa "o núcleo central da aferição da proporcionalidade", pois tem relevo para o "escrutínio de decisões discricionárias", e lida com a necessidade de oferecer argumentação "racional, persuasiva e coerente". O sopesamento trabalha com muitos valores e traz muitas dificuldades para seus usuários, valendo destacar, ainda, que ele "é, na maioria das vezes, a bússola decisiva para o resultado que soluciona o caso" 93 .

São três os passos (ou fases) do sopesamento. Todos eles buscam oferecer clareza e transparência para os diversos aspectos de desenvolvimento do ônus argumentativo que se relaciona com a intensidade da interferência estatal: "quanto mais intensa for a interferência sobre o direito fundamental, maiores deverão ser as exigências constitucionais para a justificação da interferência". Em outras palavras: "quanto mais intensa [for] a interferência sobre o direito fundamental, maiores deverão ser as exigências quanto à importância do objetivo perseguido" 94.

A primeira fase se refere à determinação da intensidade da interferência no caso concreto. Cabe, portanto, debater sobre "quão importante no caso concreto [seria] o fim perseguido por meio da interferência". A segunda fase transita na importância do objetivo (se pode ele justificar a intensidade da interferência). Neste sentido, a aferição da intensidade "da interferência e da importância do objetivo" está relacionada ao que se chama de "escala triádica", com os níveis leve, moderado e sério, relacionados "sempre (e apenas) ao caso concreto", pressupondo lidar com "decisões valorativas e argumentação moral". A terceira e última fase objetiva investigar se "a importância do objetivo perseguido pode justificar a intensidade da interferência. Isto sempre será simples quando o grau da intensidade da interferência e a importância do objetivo almejado forem avaliadas distintamente na escala triádica"95.

Pois bem, igualmente conscientes de que existem possibilidades outras de sofisticação do teste, bem como de distintas abordagens, passa-se para a análise dos argumentos de restrição ao direito fundamental à liberdade por meio de lockdown e de fechamento de vias terrestres sem base na lei como medidas de combate ao grave momento da pandemia decorrente da Covid-19.

93 KLATT, Matthias. A Máxima da Proporcionalidade: um elemento estrutural do constitucionalismo global. Trad. João Costa Neto. Observatório da Jurisdição Constitucional. Ano 7, n. 1, 2014

94 KLATT, Matthias. A Máxima da Proporcionalidade: um elemento estrutural do constitucionalismo global. Trad. João Costa Neto. Observatório da Jurisdição Constitucional. Ano 7, n. 1, 2014.

95 KLATT, Matthias. A Máxima da Proporcionalidade: um elemento estrutural do constitucionalismo global. Trad. João Costa Neto. Observatório da Jurisdição Constitucional. Ano 7, n. 1, 2014. 
Conforme visto, os "melhores" argumentos utilizados para chancelar a restrição ao direito fundamental à liberdade (lockdown e fechamento de vias terrestres sem base na Lei) são: (1) argumento de relativização dos direitos (tese de que não existem direitos absolutos) para proteção à saúde das pessoas; (2) argumento de que a Constituição Federal de 1988 já prevê algumas outras hipóteses de excepcionalidade, a exemplo da Medida Provisória; (3) argumento de que não há a possibilidade de a Constituição Federal abarcar todas as hipóteses; (4) argumento do afastamento da tese de que as medidas de restrição decorreriam do preceito político de "Estado de Exceção" por ser apenas "Legalidade Extraordinária", num misto de medidas legislativas que permitem, a qualquer tempo, a judicialização do caso concreto.

Com efeito, pode-se observar que a proteção à saúde seria, de fato, um objetivo legítimo imposto ao Estado como mandamento de proibição da proteção insuficiente. A proteção à saúde da coletividade traduziria "valores coletivos absolutos" (imposição obrigatória ao Estado), embora a proteção aos direitos restringidos também seja tutelada, e traduz valores coletivos relativos (liberalidade que faculta ao Estado). Assim, observa-se a aprovação da proposição da proteção à saúde no que se relaciona ao passo $\mathrm{n}^{\circ} \mathrm{I}$ do teste (objetivo legítimo).

Porém, num momento subsequente, não parece haver legitimidade do meio utilizado, tendo em vista que o Estado se utiliza de "via" inadequada, muito embora a consequência possa eventualmente vir a ser adequada: utilizar-se da pena de morte para a redução dos custos com a execução penal não é meio legítimo para um objetivo legítimo. Por idêntica razão, buscar um objetivo legítimo (proteger a saúde da coletividade) através da desestruturação das salvaguardas constitucionais por meio da instituição de lockdown e fechamento de vias terrestres sem base constitucional (de modo a "facilitar as coisas") não é constitucionalmente legítimo. Com efeito, observa-se a reprovação dos argumentos favoráveis à limitação da liberdade por meio de medidas de restrição no que se refere ao $n^{\circ}$ II (meio legítimo).

Sequencialmente, um meio será adequado quando, com seu auxílio, o objetivo puder ser fomentado (ou seja, algo relativamente singelo do ponto de vista da exigência). Por este ponto de vista, aparentemente parece haver aprovação quanto ao número III (adequação) sem maiores dificuldades. No entanto, uma abordagem mais sofisticada talvez sugira outra coisa - através do exemplo da "lei regulamentadora de Caça" anteriormente fornecido -, uma vez que "isolamento social" difere de lockdown e fechamento de vias. É que o primeiro é de caráter voluntário e recomendado com base 
no postulado da alteridade, contraposto à radicalidade do segundo. Apesar disso, acredita-se que tanto o lockdown quanto o fechamento de vias podem ser eventualmente eficazes para diminuir ou estrangular picos de contágio do vírus, caso se leve em conta a propagação do contágio de doentes para terceiros, e não a saúde propriamente dita das pessoas já infectadas.

Desse modo, uma observação inicial pode sugerir que as medidas restritivas serviriam como instrumentos de prevenção para que pessoas não infectadas sejam salvaguardadas do contágio, o que torna indelével o importante nível de evitar a sobrecarga dos serviços de saúde (hospitais, leitos de UTI, ambulâncias, etc.), algo que possui relevo abrangente. De outro modo, essas medidas permitiriam concluir que a saúde de todos não é, propriamente, a preocupação precípua do Estado, pois essas restrições autorizariam observar que moradores de rua ficariam vagando a céu aberto "trancados ao relento", o que deixaria nu a seletividade da própria medida de restrição. Apesar disso, o mero fomento se encontra atendido, o que confere aprovação no que se relaciona ao n III (adequação).

Prosseguindo no teste (e na reflexão), observa-se que um meio será necessário se não houver outro meio igualmente adequado que interfira de maneira menos intensa (invasiva) no direito fundamental. Dito de outra forma, de um lado, há um direito fundamental em jogo (liberdade individual e coletiva de locomoção); de outro lado, há a bandeira valorativa, evidentemente, como um mandamento e objetivo legítimo de combate aos efeitos e à propagação do novo coronavírus e, por consequência, de preservação da saúde das pessoas. No caso concreto, existem outros meios alternativos que poderiam ter sido propostos para se atingir o mesmo fim, mas não foram: (1) aprovação de legislação estabelecendo pagamento de multas; (2) instituição e implementação em todos os níveis da federação de medidas educativas de conscientização e inventivos econômicos. A partir disso, observa-se a reprovação no teste, no que se relaciona ao n IV (necessidade).

Por fim, quanto ao último passo do teste (proporcionalidade em sentido estrito), verifica-se que as razões invocadas para defender a limitação do direito fundamental à liberdade, anteriormente mencionadas, não tratam de ingressar minimamente nos contra-argumentos favoráveis à liberdade (como direito fundamental), especialmente sobre suas raízes históricas. Também não se argumenta sobre o problema da discricionariedade, cancro que carrega consigo a arbitrariedade (dilemas inerentes ao Direito Natural e ao Positivismo Jurídico e mesmo à abordagem dworkiniana), bem como sobre os fundamentos do constitucionalismo contemporâneo (fazer respeitar o Estado de Direito, proteger direitos fundamentais e conter o abuso do poder político dos governantes).

Não bastasse isso, na escala triádica, a intensidade da interferência operada pode ser classificada como "grave", aliás, a mais alta de todas, uma vez que o Estado se arvora em realizar uma medida tão grave quanto o Estado de Sítio e o Estado de Defesa sem, no entanto, o fazer de acordo com 
a Constituição Federal, mas sob o esconderijo linguístico de "legalidade extraordinária", afetando, inclusive, a normalidade democrática. Por outro lado, a proteção do direito fundamental à saúde e medidas de prevenção ao novo coronavírus também representam pretensão determinada pela Constituição Federal de 1988, mas com importância "média" no que se relaciona à determinação da gravidade do objetivo almejado. Considerados os itens anteriores (confronto entre aprovação e reprovação dos passos precedentes), é reprovada no $n^{\circ} V$ (sopesamento, ponderação ou proporcionalidade em sentido estrito).

Mencione-se, ainda, a observação de Willis Santiago Guerra Filho, já recordada anteriormente, no sentido de que a base da proporcionalidade é a preservação da dignidade humana, não o contrário. Desse modo, a limitação à liberdade com características e consequências, inclusive na esfera penal, não pode se dar num ambiente em que a proporcionalidade é operada como uma espécie de "gazua" apta a "arrombar toda e qualquer garantia constitucional" (conf. registrou o Min. Eros Grau). Devese, ao máximo possível, entender os Direitos Fundamentais como limites ao poder, sobretudo num país como o Brasil, em que as estruturas judiciais do poder (de julgar), e nas quais estão enraizados elementos sombrios, historicamente, alimentam uma burocracia que "produziu mais danos do que os que se lograram evitar".

Por tais motivos, a restrição da liberdade como direito fundamental anteriormente analisada foi aprovada em apenas dois dos cinco passos do teste. Foi, ainda, reprovada no teste da proporcionalidade, pelo que merece ser analisada sob outros enfoques, mas em quaisquer dos casos, sob uma perspectiva crítica.

\section{CONSIDERAÇÕES FINAIS}

O presente texto percorreu caminhos da reflexão crítica sobre a restrição à liberdade, considerando as raízes de um tal direito, dentro da perspetiva do direito fundamental (o caráter ôntico dos direitos fundamentais), num momento como o presente (Pandemia da Covid-19), tendo em vista o pano de fundo das recentes limitações (lockdown e restrição de vias terrestres) para efeito de combate à disseminação do vírus. Não se adotou, em absoluto, qualquer postulado de "terraplanismo jurídico". Reconhecem-se a seriedade e a gravidade do nosso tempo, sobretudo diante da visível inépcia do governo federal em termos de lançar propostas minimamente sérias de combate à disseminação do vírus, num momento em que os cadáveres dos falecidos somam montanhas de corpos. Aliás, observa-se disputas de caráter político que não contribuem para a discussão de ideias efetivas e adequadas para o devido enfrentamento da pandemia. 
Contudo, nenhuma análise sobre medidas de restrição a direitos fundamentais, como a liberdade, por exemplo, pode existir sem que se considere seriamente o problema da arbitrariedade/ discricionariedade, dentro da evolução dos dois grandes modelos de conformação do ordenamento jurídico por meio dos tempos (Direito Natural e Direito Positivo). Assim, torna-se patente que vontade de poder e decisionismos não se afiguram adequados para nenhum tipo de proteção aos direitos, mormente se observada a noção de constitucionalismo, em seu sentido mínimo de fazer respeitar o Estado de Direito, limitar ações dos governantes e preservar direitos fundamentais. Considera-se, ainda, o aspecto das transformações e do desenvolvimento do constitucionalismo, mormente no pós-guerra e o sentido de proteção contra abusos intoleráveis e muitas vezes iniciados de maneira disfarçada, até tornarem-se naturalizados atos de perversidade que decorrem da limitação dos direitos.

Postas as coisas desta maneira, o constitucionalismo também exige uma adequada compreensão da rigidez das normas constitucionais, seu sentido e significado, sem que ocorram manipulações ad hoc para aceitar violação à Constituição ao sabor de uma espécie de realismo jurídico (dos tipos americano e vienense). Compreende-se, ainda disso, a importância das discussões sobre a escolha da adequada teoria constitucional (Fallon) ou a necessidade de obediência aos ditames da filosofia da ciência, ou seja, consistência e verificabilidade (Canaris), sem que se incline por uma naturalização ou se adotem esconderijos linguísticos.

As severas medidas adotadas para restringir direitos fundamentais em nome de combate à Covid-19 são fundamentadas na suposta proporcionalidade, no suposto caráter não absoluto dos direitos, bem como no esconderijo linguístico de uma tal "legalidade extraordinária". No entanto, quando essas pilastras são submetidas ao complexo teste da proporcionalidade, a despeito de sua utilização muitas vezes equivocada pelos tribunais, acabam por mostrar que elas só têm lugar quando a Constituição é negligenciada. Dito de outra forma, as medidas restritivas supra informadas são reprovadas, pois desproporcionais.

Com isso, não se está dizendo ou defendendo que medidas de combate ao coronavírus deixem de ser implementadas, ou então que se atribua procedência ao discurso político adotado, por exemplo, pelo inepto governo federal. Não se acolhe aqui, ainda, o discurso econômico de que empregos e economia valem mais do que vidas (como forma de "abertura irrestrita do comércio", por exemplo). Esses discursos são produtos de clichês políticos perversos (de simplificação e com caráter reducionista), muitas vezes utilizados em contexto de manipulação ideológica.

Por fim, na parte introdutória do presente estudo fora apresentada a seguinte indagação: é adequada a restrição à liberdade sem base na Constituição Federal? Após checagem da validade da intervenção e da restrição desse direito fundamental, observaram-se reprovadas as medidas 
de lockdown e restrição de vias terrestres, pois desproporcionais. A rigidez constitucional e o constitucionalismo contemporâneo determinam, impõem e obrigam o afastamento do mantra sobre a "inexistência de direitos absolutos", e este texto usa a proporcionalidade justamente para proteger, e não para flexibilizar direitos.

\section{REFERÊNCIAS DAS FONTES CITADAS}

ACKERMAN, Bruce. The Emergency Constitution. The Yale Law Journal, v. 113, 2004.

AFONSO DA SILVA, Virgílio. O Proporcional e o Razoável. In: Revista dos Tribunais, vol. 798, 2002.

AGAMBEN, Giorgio. O estado de exceção provocado por uma emergência imotivada. Tradução de Luisa Rabolini. Instituto Humanitas UNISINOS, 26 fev. 2020a. Disponível em: http://www.ihu.unisinos.br/78-noticias/596584-o-estadode-excecao-provocado-por-uma-emergencia-imotivada. Acesso em: 22 jul. 2020.

AGAMBEN, Giorgio. Estado de Exceção. Tradução de Miguel Freitas da Costa. Lisboa: Edições 70, 2010.

ALEXY, Robert. Teoria dos Direitos Fundamentais. Tradução de Virgílio Afonso da Silva. 2. ed. São Paulo: Malheiros, 2015. BADIOU, Alain. Sobre a situação epidêmica. In: DAVIS, Mike et al:: Coronavírus e a luta de classes. Terra sem Amos: Brasil, 2020.

BARRETO, Vicente de Paulo (Coord.). Dicionário de Filosofia do Direito. São Leopoldo/Rio de Janeiro: Editora Unisinos/ Editora Renovar, 2006.

BAUMAN, Zygmunt. A liberdade. Tradução de M. F. Gonçalves de Azevedo. Lisboa: Editorial Estampa, 1989.

BEDIN, Gilmar Antônio. Direito Natural. Em: BARRETO, Vicente Paulo [Coord.]. Dicionário de Filosofia do Direito. São Leopoldo: Unisinos, 2009.

BOBBIO, Norberto. O positivismo jurídico: lições de filosofia do direito. trad. e notas Márcio Publiesi, Edson Bini, Carlos Rodrigues. São Paulo: Ícone, 2006.

BOBBIO, Norberto. A teoria política de Hobbes. : Thomas Hobbes. Tradução de C. Nelson Coutinho. Rio de Janeiro: Campus, 1991.

BOBBIO, Norberto. Igualdade e Liberdade. Tradução de Carlos Nelson Coutinho. 3. ed. Rio de Janeiro: Ediouro, 1997.

BOBBIO, Norberto. A era dos direitos. E-book. Trad. Carlos Nelson Coutinho; apres. Celso Lafer. Nova ed. Rio de Janeiro: Elsevier, 2004.

BRASIL. Constituição (1988). Constituição da República Federativa do Brasil. Brasília, DF: Senado Federal, 1988.

BULYGIN, Eugenio. Il positivismo giuridico. A cura di Pierluigi Chiassoni, Ricardo Guastini e Giovani Ratti. Milano: Dott. A. Giuffrè Editore, 2007.

CANARIS, Claus Wilhem. Función, estrutura y falsación de las teorias jurídicas. Trad. Daniela Brückner y Luis de Castro. Madrid: Civitas, 1995.

CANOTILHO, José Joaquim Gomes. Pós-democracia, pós-constitucionalismo, pós-positivismo. Em: SARLET, Ingo Wolfgang et al. Ontem os códigos! Hoje, as constituições: homenagem a Paulo Bonavides. São Paulo: Malheiros, 2016.

CANOTILHO, José Joaquim Gomes. Estudos sobre Direitos Fundamentais. 1. ed. Brasileira. 2. ed. portuguesa. Coimbra/São Paulo: Coimbra/Revista dos Tribunais, 2008.

CANOTILHO, J.J. Gomes. Direito Constitucional e Teoria da Constituição. 7. ed. Coimbra: Almeidina, 2003. 
CANTARINI, Paola. Direito comercial à luz do princípio da proporcionalidade: Uma análise filosófico-poética. Novas Edições, 2015.

CARBONELL, Miguel. VV.AA. (Vários autores). Neoconstitucionalismo: teoria y práctica. In: CARBONELL, Miguel; GARCÍA JARAMILLO, Leonardo (Eds.). El canón neoconstitucional. Madrid: Editorial Trotta/Instituto de Investigaciones JurídicasUNAM, 2010.

CHAVES, Leite. A nova Constituição e sua contradição ideológica. Revista de Informação Legislativa. Brasília, a. 25, n 100, out./dez. 1988.

CHIASSONI, Pierluigi. Wiener Realism. Em: Luís Duarte d'Almeida; John Gardner; Leslie Green [edit.]. Kelsen Revisited: New Essays on the Pure Theory of Law. Oxford and Portland, Oregon: Hart Publishing, 2013.

CHIASSONI, Pierluigi. El discreto placer del positivismo juridico. Bogotá: Externado, 2016.

CHIASSONI, Pierluigi. Kelsen on Natural Law Theory An Enduring Critical Affair, Revus: Journal for Constitutional Theory and Philosophy of Law, 23, 2014.

COELHO, Luiz Fernando. Aulas de introdução ao direito. Barueri-SP: Manole, 2004.

CONTI, Thomas V. Crise Tripla do Covid-19: um olhar econômico sobre políticas públicas de combate à pandemia. Disponível em: http://thomasvconti.com.br/pubs/coronavirus. Acesso em: 18 jun. 2020).

DAHL, Robert. A democracia e seus críticos. Trad. Patrícia Ribeiro. São Paulo: M. Fontes, 2012.

DIMOULIS, Dimitri; MARTINS, Leonardo. Teoria geral dos direitos fundamentais. 5. ed. São Paulo: Atlas, 2014.

DIMOULIS, Dimitri; LUNARDI, Soraya; OLIVEIRA RAMOS, Luciana; NASSAR, Paulo André; GLEZER, Eduardo. Introdução, em: Resiliência Constitucional: Compromisso Maximizador, Consensualismo Político e Desenvolvimento Gradual. São Paulo: Direito GV, 2013.

DWORKIN, Ronald. ¿Es el derecho um sistema de normas? Em: La filosofia del derecho. Ronald Dworkin (comp.), Miguel Carbonell (pról.), Javier Sáinz de los Terreros (trad.), 2. ed. México: FCE, 2014.

DWORKIN, Ronald. In: Praise of Theory. Arizona State Law Journal, vol. 29, 1997.

DWORKIN, Ronald. Reply. Arizona State Law Journal, vol. 29, 1997.

DWORKIN, Ronald. Darwin's New Bulldog. Harvard Law Review, vol. 111, 1997-1998.

ELLIOT, Ward. The Rise of Guardian Democracy: The Supreme Court's Role in the Voting Rights Disputes, 1845-1969. Cambridge: Harvard University Press, 1974.

FALLON JR., Richard. How to choose a Constitutional Theory. California Law Review, v. 87, 1999.

FERRAJOLI, Luigi. Direito e Razão: teoria do garantismo penal. 2. ed. São Paulo: Ed. Revista dos Tribunais, 2006.

FERRAJOLI, Luigi. La democracia a través de los derechos: el constitucionalismo garantista como modelo teórico y como proyecto político. Traducão de Perfecto Andrés Ibáñez. Madrid: Trotta, 2014.

GINSBURG, Tom; VERSTEEG, Mila. Covid-19: States of Emergencies: Part I and Part II. Blog Harvard Law Review, de 17 e 20 de abril de 2020 .

GODOY, Arnaldo Sampaio de Moraes. Introdução ao realismo jurídico norte-americano. Brasília: Do Autor, 2013.

GUASTINI, Ricardo. La "constitucionalización" del ordenamiento jurídico: el caso italiano. In: CARBONELL, Miguel (Ed.). Neoconstitucionalismo (s). 2. ed. Madrid: Trotta, 2005.

GUERRA FILHO, Willis Santiago; CANTARINI, Paola. Proporcionalidade. Enciclopédia Jurídica da PUC-SP, Tomo de Teoria Geral e Filosofia do Direito, São Paulo, 2017. 
JOUANJAN, Olivier. De Hans Kelsen a Friedrich Müller - método jurídico sob o paradigma pós-positivista. Em: MÜLLER, Friedrich. O novo paradigma do direito: introdução à teoria e metódica estruturantes. 3. ed., rev. atual. e ampl. São Paulo: Revista dos Tribunais, 2013.

KELSEN, Hans. The Idea of Natural Law. In: Essays in Legal and Moral Philosophy [1928]. Selected and Introduced by Ota Weinberger. Dordrecht \& Boston (Mass.): Reidel, 1973.

KELSEN, Hans. Teoria pura do direito. Trad. João Baptista Machado, 8. ed. São Paulo: WMF Martins Fontes, 2009.

KLATT, Matthias; MEISTER, Moritz. Proportionality - a benefit to human rights? Remarks on the ICON controversy. International Journal of Constitutional Law n. 10, 2012.

KLATT, Matthias; MEISTER, Moritz. La Proporcionalidad como principio constitucional universal. México: UNAM, 2017.

KLATT, Matthias; MEISTER, Moritz. A proporcionalidade como princípio constitucional universal. Revista Publicum, n. 1, 2015.

KLATT, Matthias. A Máxima da Proporcionalidade: um elemento estrutural do constitucionalismo global. Trad. João Costa Neto. Observatório da Jurisdição Constitucional. Ano 7, n. 1, 2014.

KLATT, Matthias. Argumentação jurídica e devido processo legal. Trad. Luiza A. B. Borges. Em: TOLEDO, Claudia. O pensamento de Robert Alexy como sistema. Rio de Janeiro: Forense, 2017.

KLATT, Matthias; MEISTER, Moritz. The Constitutional Structure of Proportionality. Oxford, 2012.

KUNTZ, Rolf. A descoberta da igualdade como condição de justiça. In: FARIA, José Eduardo (Org.). Direitos Humanos, Direitos Sociais e Justiça. São Paulo: Malheiros, 2005.

LOSANO, Mário. Sistema e estrutura no direito: o século XX. v. II. Trad. de Luca Lamberti. São Paulo: Editora WMF Martins Fontes, 2010.

MENAND, Louis. The metaphysical club. New York: Farrar, Straus and Giroux, 2001.

MENDES, Alexandre Fabiano. Liberdade. In: BARRETO, Vicente de Paulo (Coord.). Dicionário de Filosofia do Direito. São Leopoldo/Rio de Janeiro: Editora Unisinos/Editora Renovar, 2006.

MIRANDA, Jorge. Os grandes princípios constitucionais e a jurisprudência da crise em Portugal. Em: SARLET, Ingo Wolfgang et al. Ontem os códigos! Hoje, as constituições: homenagem a Paulo Bonavides. São Paulo: Malheiros, 2016.

MIRANDA, Jorge. Contributo para uma teoria da Inconstitucionalidade. Coimbra: Coimbra editora, 1967.

MOORE, Michael. The Constitution as Hard Law. Constitutional Commentary, vol. 6, 1989.

MORAIS, Fausto Santos de. Hermenêutica e pretensão de correção: uma revisão crítica da aplicação do princípio da proporcionalidade pelo Supremo Tribunal Federal. São Leopoldo: UNISINOS, 2013.

NEVES, Marcelo. A constitucionalização simbólica. 2. ed. São Paulo: WMF Martins Fontes, 2007.

PÁDUA, Thiago Aguiar. Ao Vencedor, o Supremo Tribunal Federal: O Teatro das "Sombras" Constitucionais (Uma [Des] Leitura). 409f. Tese (Doutorado em Direito) - Centro Universitário do Distrito Federal, Brasília, 2020.

PÁDUA, Thiago Aguiar; RODRIGUES DE PAULA, Lucas. O "Museu de Cera" das Ideias Constitucionais: a mudança de entendimento do STF sobre o processo de Governadores por crime comum, sem autorização legislativa, submetida ao "teste da proporcionalidade" de Matthias Klatt. Cadernos de Direito v. 1, n. 1, 2019.

PÁDUA, Thiago Aguiar; BRAGANÇA FERREIRA, Fabio; OLIVEIRA, Ana Carolina Borges de. A Outra Realidade: o panconstitucionalismo nos Istaites. Revista Brasileira de Políticas Públicas, v. 5, n. Esp., 2015.

PÉREZ TAPIAS, José Antônio. Entre o risco e o medo, a biopolítica em alta. Instituto Humanitas UNISINOS, 17 mar. 2020. Disponível em: http://www.ihu.unisinos.br/78-noticias/597147-entre-o-risco-e-o-medo-a-biopolitica-em-alta. Acesso 
em: 20 jun. 2020.

PISARELLO, Gerardo. Los derechos sociales y sus garantías: elementos para una reconstrucción. Madrid: Trotta, 2007.

POSNER, Richard. Conceptions of legal "Theory": a Response to Ronald Dworkin. Arizona State Law Journal, vol. 29, 1997.

PRIETO SANCHÍS, Luis. El constitucionalismo de los derechos. In: CARBONELL, Miguel (Ed.). Teoria del neoconstitucionalismo: ensayos escogidos. Madrid: Editorial Trotta/Instituto de Investigaciones Jurídicas- UNAM, 2007.

RAWLS, John. A theory of justice. Cambridge (MA), The Belknap Press, 1971.

REALE, Miguel. A dinâmica do direito numa sociedade em mudança. Em: Estudos de filosofia e ciência do direito. São Paulo: Saraiva, 1978.

ROSENFELD, Michel. Modern Constitutionalism as Interplay Between Identity and Diversity. In: ROSENFELD, Michel (Ed.). Constitutionalism, Identity, Difference, and Legitimacy - theoretical perspectives. Durham and London: Duke University Press, 1994.

SARLET, Ingo Wolfgang. Curso de Direito Constitucional. In: SARLET, Ingo Wolfgang; MARINONI, Luis Guilherme; MITIDIERO Daniel (Org.). 6. Ed. São Paulo, SP: Saraiva, 2017.

SARLET, Ingo Wolfgang; MARINONI, Luiz Guilherme; MITIDIERO, Daniel. Curso de Direito Constitucional. São Paulo: Editora Revista dos Tribunais, 2012.

SARLET, Ingo Wolfgang. Direitos Fundamentais e Direito Privado: algumas considerações em torno da vinculação dos particulares aos direitos fundamentais. In: . (Org.). A constituição concretizada. Porto Alegre: Livraria do Advogado, 2000.

SARTRE, Jean Paul. O ser e o nada: ensaio de ontologia fenomenológica. Tradução: Paulo Perdigão. 6. ed. Rio de Janeiro: Vozes, 1998.

SERRANO, Pedro. É a ciência, estúpido! Carta Capital de 20 de maio de 2020.

SILVA, José Afonso da. Teoria do Conhecimento Constitucional. São Paulo: Malheiros, 2014.

SILVA, José Afonso da. Curso de direito constitucional positivo. 20. ed. São Paulo: Malheiros, 2002.

SILVA, José Afonso da. Aplicabilidade das Normas Constitucionais. 3. ed. rev. ampl. atual. São Paulo: Malheiros Editores, 1998.

STRECK, Lenio Luiz. Verdade e Consenso: constituição, hermenêutica e teorias discursivas. 5. ed. São Paulo: Saraiva, 2014.

STRECK, Lenio Luiz; ORTIZ MATOS, Daniel. Mitos sobre o positivismo jurídico: uma leitura para além do senso comum teórico. Revista UNIFESO - Humanas e Sociais, Vol. 1, n. 1, 2014.

STRECK, Lenio Luiz; RAATZ, I.; MORBACH, Gilberto. Desmistificando o positivismo de Jeremy Bentham: sua codificação utilitarista e a rejeição ao stare decisis como autorização para errar por último. Revista Brasileira de Direito Processual, v. 99, p. 221-242, 2017.

STRECK, Lenio Luiz. Kelsen e o positivismo jurídico contemporâneo: notas de um (possível) acerto de contas. Revista del Posgrado En Derecho de la UNAM, v. 9, p. 145-169, 2018.

STRECK, Lenio. OPINIÃO Lockdown e Estado de Sítio: operar uma unha não exige anestesia geral! ConJur de 11 de maio de 2020.

SUNSTEIN, Cass. From Theory to Practice Order of the Coif Lecture: Response. Arizona State Law Journal, vol. 29, 1997.

TAVARES, Marcelo Leonardo. A restrição à liberdade e o Conselho da República em época de coronavírus. Disponível em: < https://www.conjur.com.br/2020-mai-01/marcelo-tavares-restricao-liberdade-conselho-republica>. Acesso em: 20 jul. 2020. 
TEUBNER, Gunther. Fragmentos constitucionais: constitucionalismo social na globalização. São Paulo: Saraiva, 2016

TRIBE, Laurence H.; GUDRIDGE, Patrick. The Anti-Emergency Constitution. The Yale Law Journal, v. 113, 2004.

TSAKYRAKIS, Stavros. Proportionality: An assault on human rights?, 7 I NT ' L J. C ONST. L. (I.CON) 4682009.

ZIBECHI, Raúl. Coronavírus: a militarização das crises. In: DAVIS, Mike et al.: Coronavírus e a luta de classes. Terra sem Amos: Brasil, 2020.

ŽIŽEK, Slavoj. Monitorar e Punir? Sim, por favor! Tradução de Leonardo Mendonça. Publicado em 16 de março de 2020. Disponível em: https://thephilosophicalsalon.com/monitor-and-punish-yes-please/. Acesso em: 28 jul. 2020.

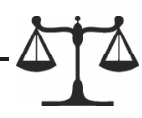

